Historic, Archive Document

Do not assume content reflects current scientific knowledge, policies, or practices. 



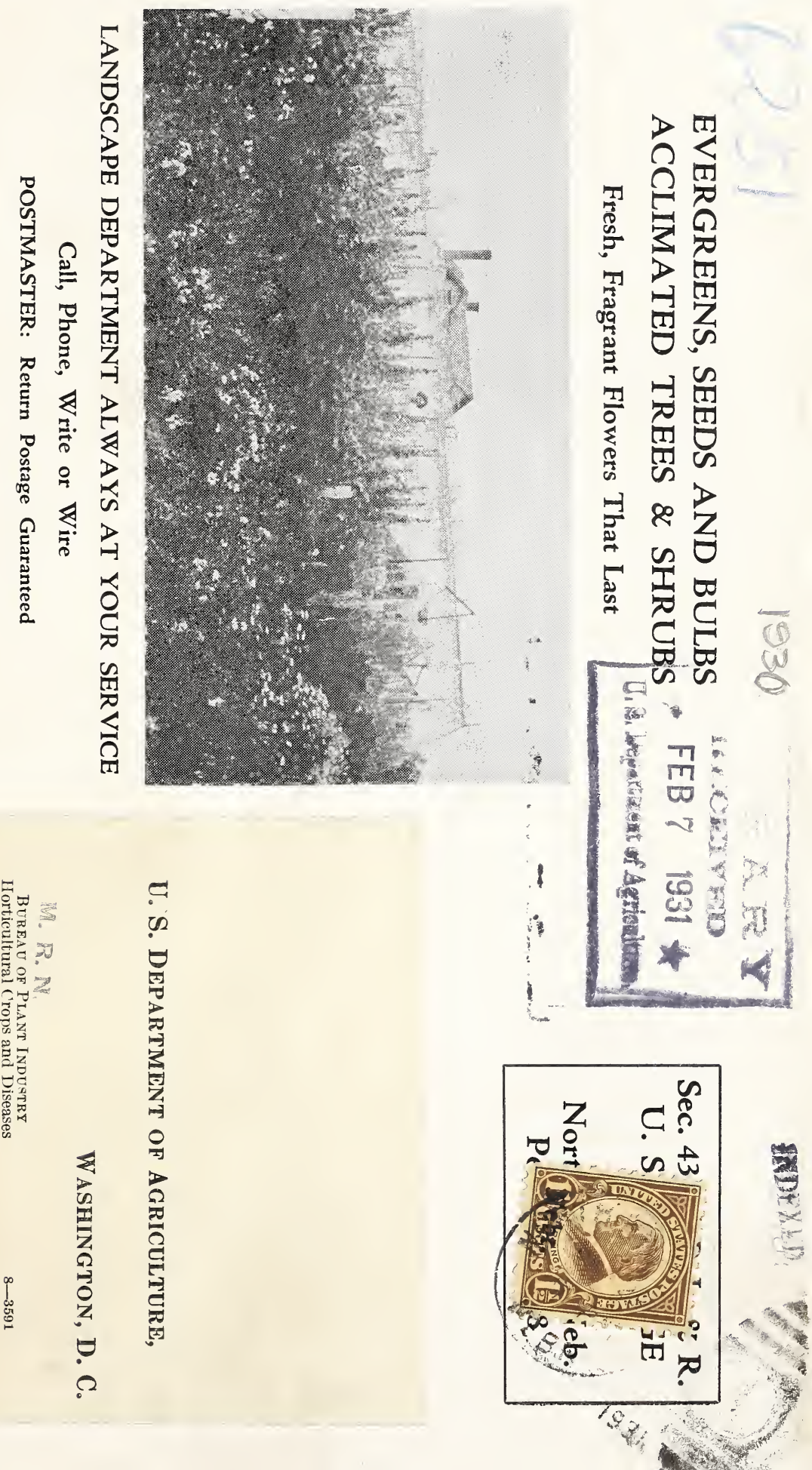




\section{EVERGREENS}

All B. \& B. (Balled and Rurlapped)

BLACK HILLS SPRUCE. The most satisfactory of all the spruces. Ideal for foundation, windbreak or specimen plantings. 5 at 10 rate.

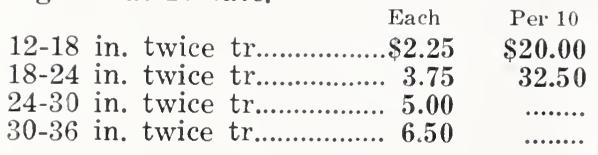

COLORADO BLUE SPRUCE. The finest of ornamental evergreens. Ours are all good blue color.

$\begin{array}{cc}\text { Bushy } & \begin{array}{c}\text { Lighter } \\ \text { Grade }\end{array} \\ 12-18 \text { in. .......................55.00 } & \mathbf{\$ 3 . 5 0} \\ 24-30 \text { in. extra.............. } 12.00 & \mathbf{7 . 5 0} \\ 36-36 \text { in. extra............ } 15.00 & \ldots \ldots \ldots\end{array}$

KOSTERS BLUE SPRUCE. $2 \mathrm{ft}$, $\$ 17.50$ each.

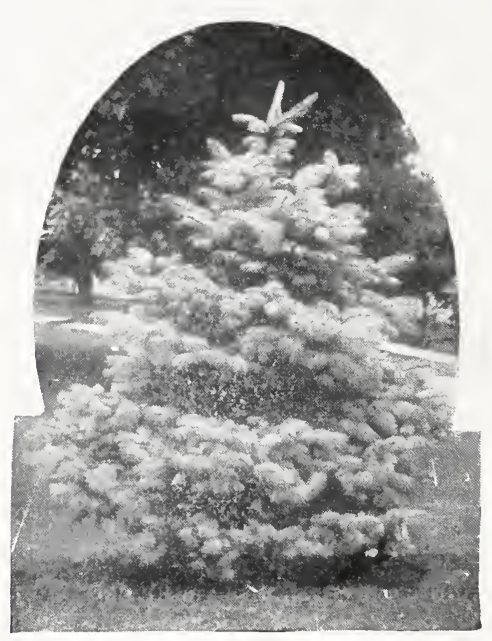

Co'orado Blue Spruce

RED CEDAR. Juniperus virginiana. 4-5 ft., \$8.75 each; 3-4 ft., \$6.25 each; $2-3 \mathrm{ft}$., $\$ 4.00$ each.

SABINA Juniper. Medium dwarf. $1^{1 / 2-2}$ ft., $\$ 6.00$ each; $24-30$ in., $\$ 7.50$ each.

SWEDISH Juniper. 18-24 in., \$6.50 each.

PFITZERS Juniper. $24-30$ in. $\$ 8.00$ each.

PFITZERS Juniper. 30-36 inches, $\$ 12.00$ each.

PROSTRATE Juniper. 30-36 in., $\$ 9.00$ each.

CHINESE JUNIPER. 11/2-2 ft., $\$ 6.50$ each.

PYRAMIDAL ARBOR VITAE. 2 ft. $\$ 6.00$ each.

MUGHO PINE. Dwarf. 10-12 in. spread $\$ 4.00$ each; $18-24$ in. spread, $\$ 7.50$ each.

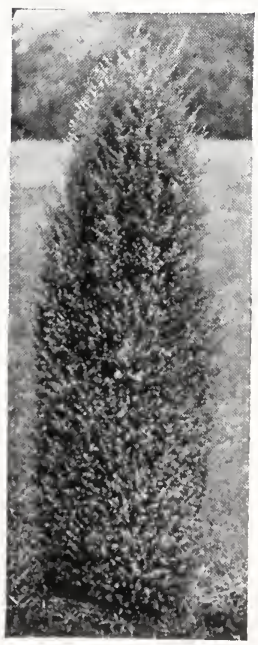

\section{Black Hills Spruce Seedlings}

We are in position to furnish Black hills spruce direct from the Black Hills of South Dakota.

Plant in beds the first year and keep shaded. Do not expose roots to sun or wind at any time.

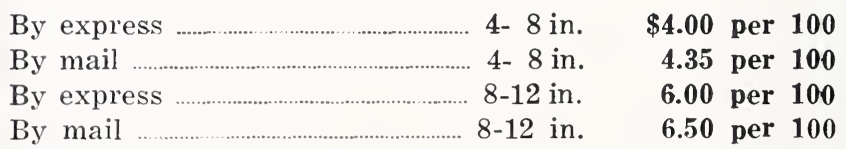

Brady, Nebraska,

April 19.

Dear Sirs: The flowers that you sent for Easter were received in good time and in wonderful condition and I certainly want to thank you for the same. Assuring you of my future business, I am, yours truly,

Harlen Discoe. 


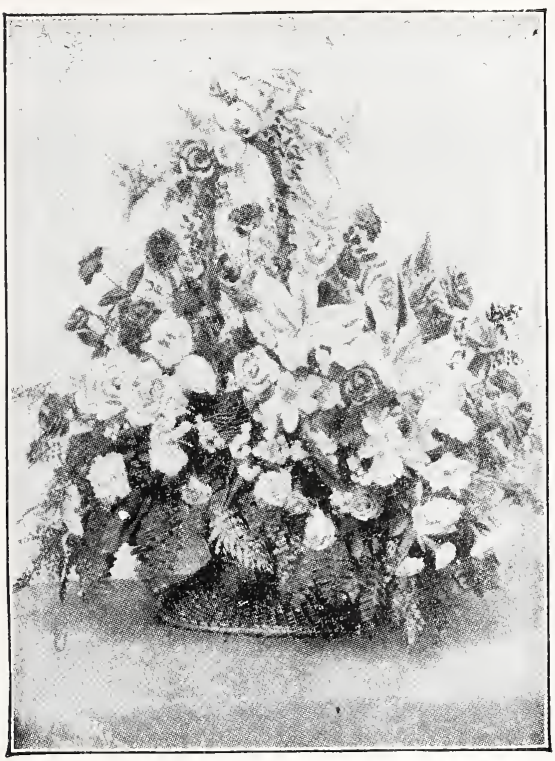

Everybody Loves Flowers

Cut flowers or a nice blooming potp'ant for Mother on yours or her birthday-A Wedding Anniversary, Easter, Mother's Day, Christmas, Thanksgiving, all bring the cheer we need. Our two speedy delivery cars are at your service, anytime, day or night (Phone 345 ).

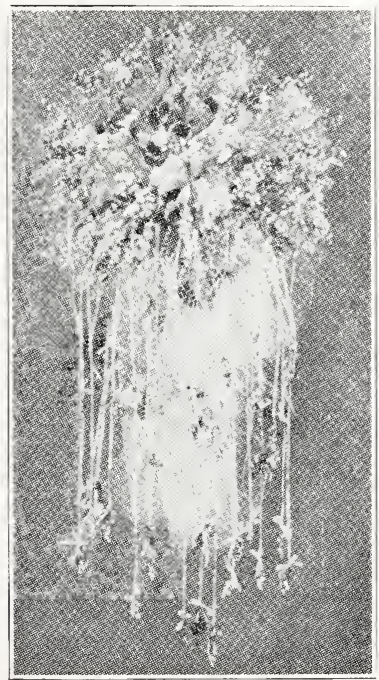

Bridal Bouquet

\section{Cut Flowers}

Most cut flowers produced during the various seasons are of our own growing. Prices are all per dozen.

CARNATIONS. From Sept. to July. \$1.50, $\$ 2.00, \$ 2.50$. Laddie Type, \$3.00.

ROSES. The year around. \$2, \$3, \$4, \$5 to $\$ 10$ per dozen.

POMPONS, SMALL CHRYSANTHEMUMS, Sept. to Jan. \$1.00, \$1.50, \$2.00 and \$3.00.

CHRYSANTHEMUMS, large and medium size. $\$ 3, \$ 4, \$ 5, \$ 6 \$ 7.50$ and $\$ 10.00$.

NARCISSUS. Yellow and White, Nov, to Jan. \$1.50, \$2.00 and \$2.50.

DAFFODILS. January to April. $\$ 2.00, \$ 2.50$ and $\$ 3.00$.

CALLA LILIES. Nov. to May. $\$ 5.00, \$ 6.00$ and $\$ 7.50$

CALLENDULA ORANGE. $\$ 1.50, \$ 2.00$ and $\$ 2.50$.

GLADIOLUS. May to Sept. 100 varieties. $\$ 1.00, \$ 1.50, \$ 2.00$ to $\$ 4.00$.

EASTER LILIES. $\$ 5.00$ to $\$ 6.00$.

SWEET PEAS. 50c and 75c. Bunches $\$ 1.00$, $\$ 1.50$ and up.

Prices of cut flowers vary with cost of production, quality and length of stem. The short stemmed ones are always cheaper.

\section{Flowers by Telegraph}

Flowers delivered anywhere through the Florists' Telegraph Delivery Association, composed of over 4,000 of the most reliable florists in the country. We can deliver flowers and plants anywhere in the United States and Canada, and to many points in Europe on short notice. There is no additiona! charge for this service, except the cost of the telegram when it is necessary to wire.

A splendid way to remember your friends no matter where they live is to "Say it with Flowers."

\section{Flowers for the Sick}

We make selections of our choice that are fresh cut, long-keeping and particularly adapted for vase, bouquets in the sick room.

\section{OUR SPECIAL SUNSHINE BOXES}

Prices................... \$2.00, \$3.00, $\$ 4.00$ and $\$ 5.00$ Extra fine ................................................. $\$ 100$

Add 40 cents for express on the smaller boxes. 50 cents on the larger. $15 \mathrm{c}$ for $\mathrm{P}$. P. and $25 \mathrm{c}$ extra for Special Delivery.

\section{Our Sunshine Baskets of Flowers}

These are appropriate for any occasion, and are especially desirable for sick rooms, birthday presents, parties, store and bank openings, etc.

All baskets are supplied with tin liners to hold water so that flowers will keep well.

We make them in two styles-the high handle, as illustrated, and the low handle.

The low handle basket at $\$ 5.00, \$ 6.00$ and $\$ 8.00$.

The high handle basket at $\$ 8.00, \$ 10.00$, $\$ 12.50$, \$15.00 and up.

Express charges 50 to 75 cents.

Wedding bouquets and Decoration of Home and Church are our specialty. We will be very glad to give our suggestions in regard to bouquets for the bride, bridesmaids, flowergirls, and corsages for the mothers; also suggestions for the decoration of home and church.

We are making SPECIALS in Wedding Bouguets at $\$ 5.00, \$ 7.50, \$ 10.00, \$ 15.00$ and $\$ 20.00$. 


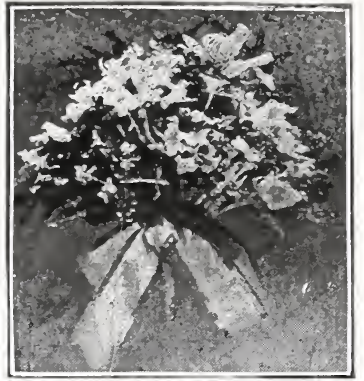

\section{Houseplants}

Mother always loves to take care of a few nice houseplants.

FUCHSIAS, everblooming, 15c, 25c to $\$ 3.00$. GERANIUMS, all colors, $10 \mathrm{c}, 15 \mathrm{c}$ to $50 \mathrm{c}$.

MARTHA WASHINGTON GERANIUMS, $25 \mathrm{c}$ to $\$ 2.00$ each.

PRIMROSES, 25c to $\$ 2.00$.

CYCLAMEN-ALPENVEILCHEN, 75c, $\$ 1.00$,

$\$ 1.50, \$ 2.00, \$ 2.50, \$ 3.00, \$ 4.00$ and $\$ 5.00$.

HYACINTH plants in bloom, $25 \mathrm{c}$ to $\$ 2.50$.

CALLA LILY plants in bloom, $\$ 1.00$ to

$\$ 2.50$.

GOLDEN CALLA LILY, $\$ 1.00$ to $\$ 2.00$.

HYDRANGEAS for Easter. $\$ 2.00$ to $\$ 7.50$. ROSEBUSHES in bloom. $\$ 1.50$ to $\$ 5.00$.

ROSEBUSHES, grown in pots, not in bloom, for house and outdoors, $\$ 1.00$ to $\$ 2.00$.

TRAILING VINES, WANDERING JEW,

IVY, VINCA, LOBELIAS, 10c to 50c.

Our beauty IVY GERANIUM, 25c to 50c.

EASTER LILY plants in bloom, $\$ 1.50, \$ 2.00$, $\$ 3.00, \$ 4.00$ and $\$ 5.00$.

EASTER LILY, not in bloom, but in bud, $\$ 1.00, \$ 1.50$ and $\$ 2.00$.

\section{Ferns}

ASPARAGUS PLUMOSUS FERNS, 25c, 35c, $50 \mathrm{c}$ each.

ASPARAGUS, SPRENGERII FERNS, 25c, $35 \mathrm{c}, 50 \mathrm{c}$ each.

BOSTON FERNS, a splendid stock of these desirables from $75 \mathrm{c}$ to $\$ 5.00$ each.

\section{Corsages}

Tied with ribbon to match the flowers and pearl headed pany them.

Are considered the "proper" bouquets to wear at dances,

\section{Shoulder Bouquets}

and all social functions. They are made with a

On Your Birthday, Send Your Mother Some Flowers

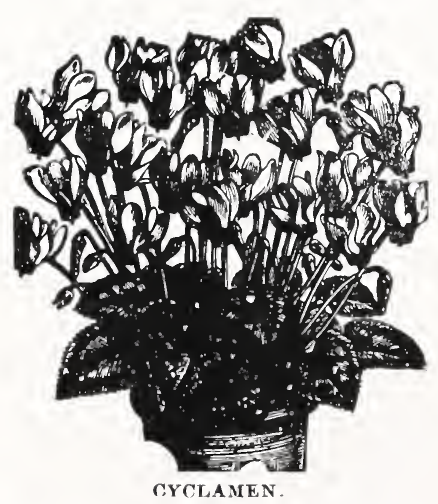

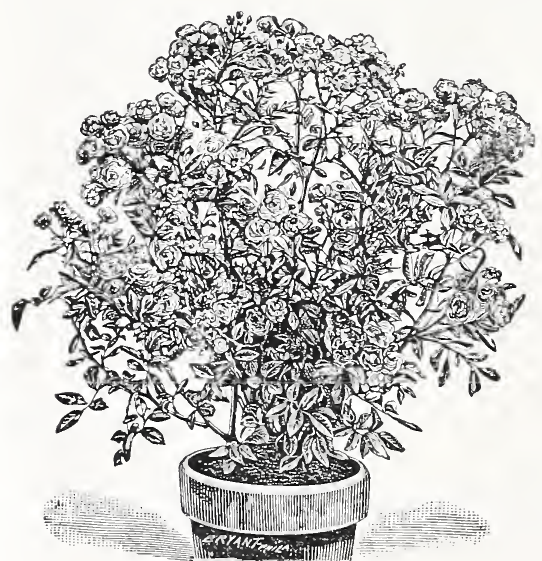

Sidney, Nebraska.

Dear Sir: I want to tell you that the bird came all $\mathrm{O}$. K. and I am surely delighted with him. I have only had him one afternoon but he is a wonder. He started right in singing and such notes as he has are wonderful. I feel as if $I$ have the best of the bargain and right now I want to thank you for sending me such a singer, also thanks for the sunflower seed and with best wishes.

Nelle Horst.

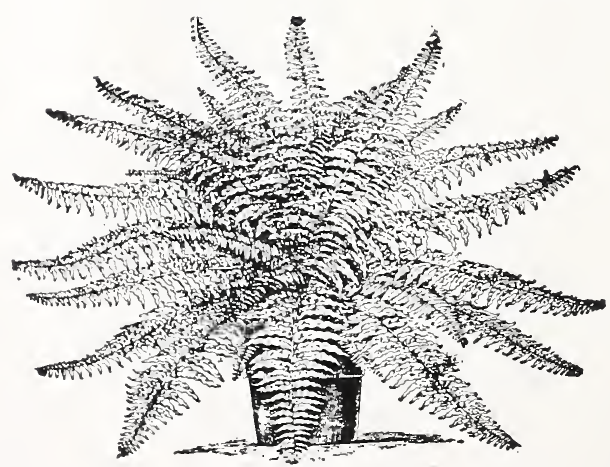




\section{PRICES ON BEDDING PLANTS, ETC.}

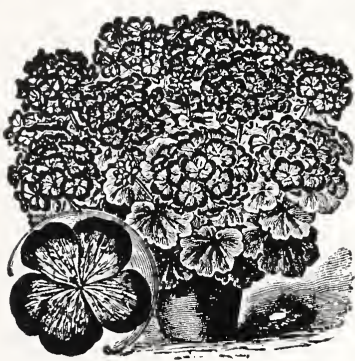

Alyssum, sweet, 2-inch pots..\$0.10 $\$ 0.70 \$ 4.50$ Alyssum, double, 2-inch pots $\quad \mathbf{1 5} \quad \mathbf{1 . 5 0} \quad \mathbf{9 . 0 0}$

Antirrhinum (Snapdragon) 2 -inch pots ........................... $\quad .10 \quad 80 \quad 5.00$

Antirrhinum Leovenmaul, 3inch pots ............................... $20 \quad 200$

Asparagus Sprengerii, 3-inch $\quad .20 \quad \mathbf{2 . 0 0} \quad \mathbf{1 2 . 0 0}$

Asparagus Sprengerii, 4-inch $\quad \mathbf{3 0} \quad \mathbf{3 . 0 0} \quad \mathbf{2 4 . 0 0}$

Asparagus Plumosus fine needles, small ..................... $\quad .20 \quad 2.00$

Asparagus Plumosus fine needles, larger ...................... $\quad .35$

Cannas, dormant roots,

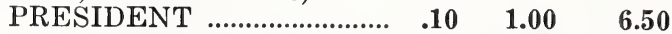

$\begin{array}{lllll}\text { Cannas, pink and yellow........ } & .10 & \mathbf{1 . 0 0} & \mathbf{6 . 5 0}\end{array}$

Cannas, started in sand............

Cannas, from pots ................. $\quad .20 \quad \mathbf{2 . 0 0} \quad \mathbf{1 2 . 0 0}$

$\begin{array}{lllll}\text { Coleus, foliage plants............. } & \mathbf{. 1 0} & \mathbf{1 . 0 0} & \mathbf{6 . 0 0}\end{array}$

Coleus, larger plant................. $\quad .15 \quad \mathbf{1 . 5 0} \quad \mathbf{9 . 0 0}$

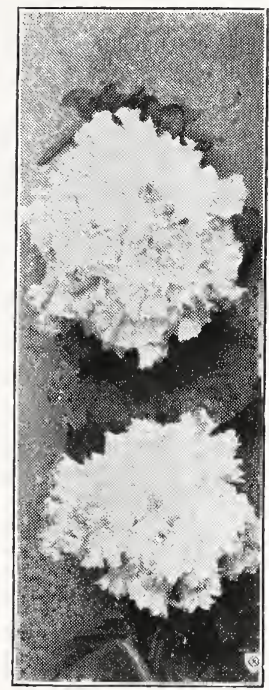

Other foliage plant and Joseph Coat

Same price as Coleus

\begin{tabular}{|c|c|c|c|}
\hline Dracema, palm-like for center & .30 & 3.00 & 23.00 \\
\hline Dracema, large ........................ & .50 & 5.00 & \\
\hline Dusty Miller .............................. & .10 & 1.00 & 6.00 \\
\hline Geraniums, small .................... & .10 & 1.00 & 6.00 \\
\hline Geraniums, medium ................ & .20 & 2.00 & 12.00 \\
\hline Geraniums, large ................... & .25 & 2.50 & 20.00 \\
\hline Geraniums, extra large .......... & .35 & 3.50 & \\
\hline Heliotrope ................................... & .15 & 1.50 & 9.00 \\
\hline Ivy, hardy English................... & .25 & 2.50 & \\
\hline Ivy, German ................................ & .15 & 1.50 & \\
\hline Lobelia, star of love................. & .10 & 1.00 & 5.50 \\
\hline Marguerites, white single........ & .15 & 1.50 & \\
\hline terites, double, large...... & .20 & 2.00 & \\
\hline erites, yellow ................. & .25 & 2.50 & \\
\hline , heavenly rose............ & .10 & 1.00 & 6.00 \\
\hline Petunia, from larger pots...... & .20 & 2.00 & 12.00 \\
\hline Petunia, double varieties........ & .25 & 2.50 & \\
\hline Salvia, scarlet sage................. & .10 & 1.00 & 6.00 \\
\hline Salvia, fireball .......................... & .15 & 1.50 & 8.00 \\
\hline Salvia, fireball ........................... & .25 & 2.50 & \\
\hline Verbenas, also 20 and $25 \mathrm{c}$ ea. & .10 & 1.00 & \\
\hline Vinca, white and green............ & .10 & 1.00 & \\
\hline Vinca, 20 c each, $\$ 2.50$ per doz. & .35 & 3.50 & \\
\hline
\end{tabular}

Add Postage. Larger Shipments by Express Collect.

\section{SEEDLING BEDDING PLANTS}

Snapdragon, mixed colors; Calendula, lemon and orange color, Daisies, Feverfew, Marigold, Zinnia, large mixed, Larkspur, Petunias, Verbenas. Price 50c per dozen. Mixed Asters, mixed colors, 40c per dozen, 3 dozen for $\$ 1.00$. Stocks, summer, 70c per dozen. Flowering Tobacco, 75c per dozen, add postage. 


\section{POT GROWN PERENNIALS}
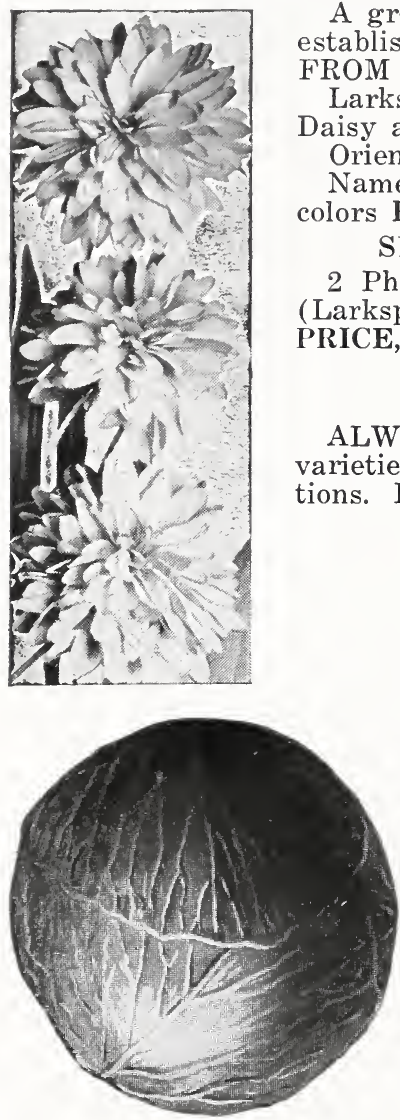

A great favorite with our customers as these are well established when you receive them in May or June. TAKEN FROM POTS.

Larkspur, (Rittersporn) Flax, Lychnis Gaillardia, Shasta Daisy and Columbine, 25c each, $\$ 2.50$ per dozen.

Oriental Poppies, 35c each, $\$ 3.50$ per dozen.

Named Phlox, 25c each, $\$ 2.50$ per dozen. Specify colors; colors Pink, White or red.

\section{SPECIAL COLLECTION OF PERENNIALS}

2 Phlox, 1 Flax, 1 Columbine, 1 Daisy, 3 Delphinium (Larkspur) 1 Lychnis, 2 Poppy, 1 Gaillardia, REGULAR PRICE, $\$ 3.20$. Our special price, $\$ 2.75$ postpaid for all.

\section{VEGETABLE PLANTS}

ALWAYS SPECIFY, earliest, mid-season or late. 3 varieties. On large quantities, write for special quotations. PRICES FOLLOWING ARE ALL POSTPAID.

\begin{tabular}{|c|c|c|c|c|}
\hline Cabbage ..... & $\begin{array}{l}\text { Per Doz. } \\
\$ 0.15\end{array}$ & $\begin{array}{c}50 \\
\$ 0.40\end{array}$ & $\begin{array}{c}100 \\
\$ 0.75\end{array}$ & $\begin{array}{r}1,000 \\
\$ 5.00\end{array}$ \\
\hline Cauliflower, & & & & \\
\hline (Blumenkohl) & .15 & 40 & .75 & 6.00 \\
\hline Celery & .15 & .40 & .75 & \\
\hline Egg Plant, & & & & \\
\hline (Early Beauty) ... & .25 & .60 & 1.00 & \\
\hline eppers & .25 & .60 & 1.00 & \\
\hline weet Potatoes ................. & .25 & .60 & 1.00 & \\
\hline omatoes ............................. & .20 & .60 & 1.00 & $\mathbf{7 . 5}$ \\
\hline
\end{tabular}

Tomatoes, pot plants (exp. only) $10 \mathrm{c}$ and $15 \mathrm{c}$ according to size.

\begin{tabular}{|c|c|c|}
\hline Red Cabbage ..................... & .15 & .40 \\
\hline Versing & .15 & .40 \\
\hline Kohlrabi ............................. & .15 & .40 \\
\hline $\begin{array}{l}\text { Brussels Sprouts, } \\
\text { (Rosenkohl) }\end{array}$ & .15 & .40 \\
\hline Parsley, (Peterselie).... & .15 & .40 \\
\hline
\end{tabular}

Onion Plants ................................................................

Onion sets red or yellow, per lb. 25c; 5 lbs. for $\$ 1.00$.

\section{FILLING PORCH BOXES}

We are making up special assortments of plants for porch boxes, our selection, at the following prices:
12 plants@......\$1.75
25 plants@......3.25
Prices Postpaid

When boxes are brought to us or called for, we can fill them for $\$ 1.00$ to $\$ 1.50$ per square foot.

\section{PRICES-HANGING BASKETS}

Made of wire, electric welded, with hangers.

$40 \mathrm{c} 50 \mathrm{c} \quad 60 \mathrm{c} \quad 75 \mathrm{c}$

\section{PLANTS FOR PORCH BOXES AND HANGING BASKETS}

Geraniums, large. $30 \mathrm{c}$ to $40 \mathrm{c}$ each, 3 for $\$ 1.00$.

Petunias, 10c, 15c, 20c. 25c and $30 \mathrm{c}$.

Vinca, striped leaves, $10 \mathrm{c}, 15 \mathrm{c}, 25 \mathrm{c}$ and $30 \mathrm{c}$.

Ferns, 20c, 25c and 35c.

California pink, $15 \mathrm{c}$ and $20 \mathrm{c}$.

Dracema, center plant, $50 \mathrm{c}$ and $75 \mathrm{c}$.

MOSS FOR HANGING BASKETS. 1/2 lb. 30c, 1 lb. 50c. (One lb.

is sufficient to line the average basket.)

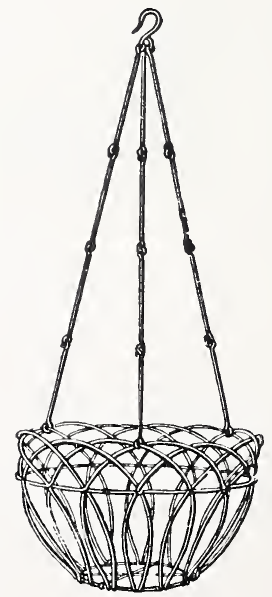




\section{SUMMER FLOWERING BULBS}

We have about 180 varieties of Dahlias, Gladiolus, Canas, Lilies, Tuberoses and others. Plant in quantity for flowers all summer.

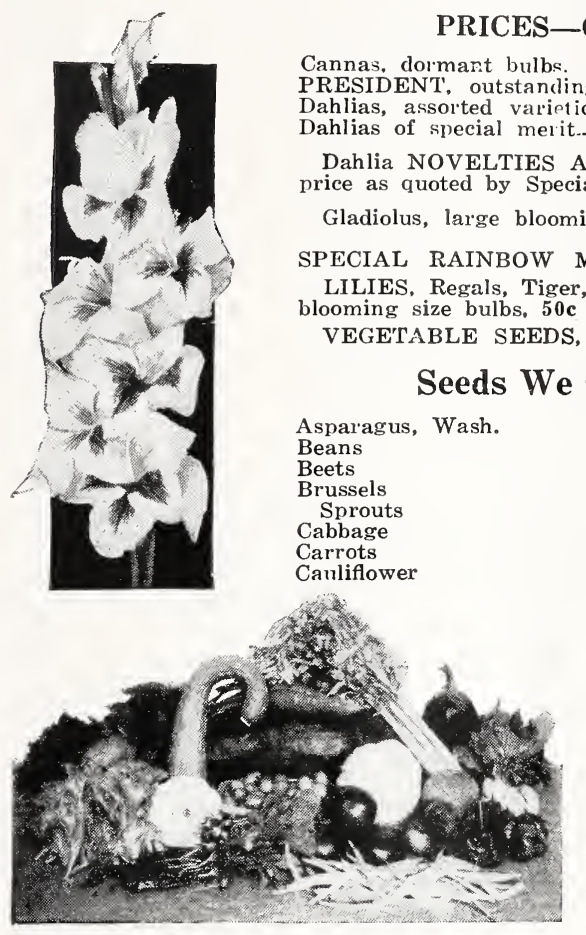
price as quoted by Specialists.

Asparagus, Wash.

Brussels

Sprouts

Cabbage

Carrots

Cauliflower

GENERAL ASSORTMENT

$\begin{array}{lllllll} & \text { Each } & 6 & 12 & 25 & 50 & 100\end{array}$ $\begin{array}{lllllll}\$ 0.15 & \$ 0.75 & \$ 1.30 & \$ 2.40 & \$ 4.50 & \$ 7.50\end{array}$

$\begin{array}{llllll}.15 & .75 & 1.30 & 2.40 & 4.50 & 7.50\end{array}$

$\begin{array}{llllll}.25 & 1.25 & \mathbf{2 . 4 0} & \mathbf{4 . 5 0} & \mathbf{7 . 5 0} & \mathbf{1 4 . 0 0}\end{array}$

ND ARISTOCRATS, we can furnish at same

Gladiolus, large blooming size bulbs, finest varieties.

$\begin{array}{llllll}12 & 25 & 50 & 100\end{array}$

LILIES, Regals, Tiger, Pink, Madonna and St. Joseph, extra strong ooming size bulbs, 50 c each, $12, \$ 5.00 ; 25, \$ 9.00$.

\section{Seeds We Can Save You Money On}

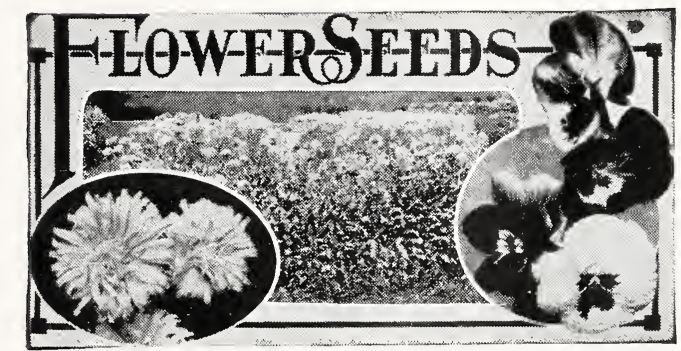

Celeriac

(Root celery)

Celery

Chard, Swiss

Cucumbers

Egg Plant

Kale

Kohlrabi

Peas

Peppers

Radish

ALFALFA or large quantities of vegetable or flower seed write for special prices.

\section{FLOWER SEEDS}

Lupinus

Marigold

Mixed Flower seed

Mourning Bride

Nasturtiums

Pansies

Petunia

Snapdragon

Sweet William

Verbena

Zinnia

Alyssum

Antirrhinum

Balloon Vine

Balsam

Calendula

Calliopsis

Candy Tuft

\section{Sweet Peas}

Spencer Varieties, 6 distinctive colors, red, white, blue, lavender, pink, orange. Pkt. 10c; 1 oz., 20c; 6 ozs.. \$1 nn
Peony Poppy

Phlox

Poppies

Portulaca

Straw flowe

Scarlet Runner

Carration

Castor Bean

Centaurea

Cockscomb

Cosmos

Daisies

Dianthus

Four O'Clock

Gaillardia

Haillyrdia double
Julesburg. Colorarlo.

February 20.

Sirs: Received the spray thic morning and just wanted to write and say-the flowers were beautiful and I was very much p'eased. Don't know that I ever saw a prettier spray.

Many thanks for your promptness.

Yours respectfully,

Mrs. Bruce Campbell.

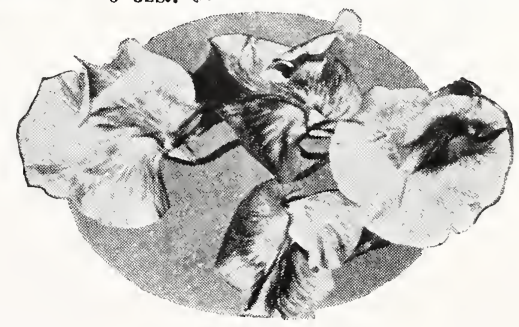




\section{Fertilizers-Plant Foods}

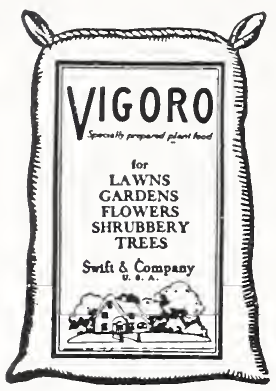

VIGORO, wholesale and retail. We are the authorized agents for this territory. Postpaid, $1 \mathrm{lb}$. for $17 \mathrm{c}$; 5 lbs. for $65 \mathrm{c}$.

Express or freight, 25 lbs. $\$ 1.75 ; 50$ lbs., $\$ 3.00 ; 100$ lbs., $\$ 5.00$.

PLANT LIFE, (Liquid). A fine plant food. 32c per can postpaid.

FLORANID. Plant food (send for our literature) $1 \frac{1}{2}$ oz. can, 22c prepaid.

NITROPHOSKA. Plant food (send for our literature), 2 oz. can 22 c postpaid.

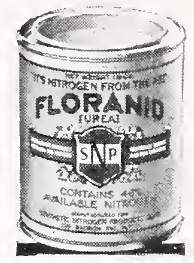

\section{Insecticides}

EVERGREEN, (non-poisonous). Gets mealy bugs. 11/2 oz. bottle 38c prepaid.

VOLCK. A very effective spray for red spider, mealy bug, scale, white fly and aphis. Safe to use on tender plants. Postpaid, $1 / 2$ pint, 68c; 1 pint, 90c; 1 quart, $\$ 1.30$.

INSECT POWDER. In small packages, 17c per package, postpaid.

SULPHUR. Yellow sulphur. To spread around evergreens, keeps animals away. Postpaid, 1/4 lb., 9c; 1/2 lb. 16c; 1 lb. 24c.

\section{Lawn Grass Seed}

(Recleaned, No Weeds)

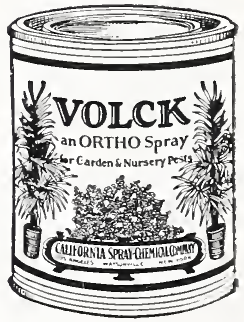

Postpaid, lb. package, 55c; 5 lbs. $\$ 2.45$.

Express or freight, 5 lbs. $\$ 2.25 ; 10$ lbs. $\$ 4.25 ; 20$ lbs. $\$ 8.00$.

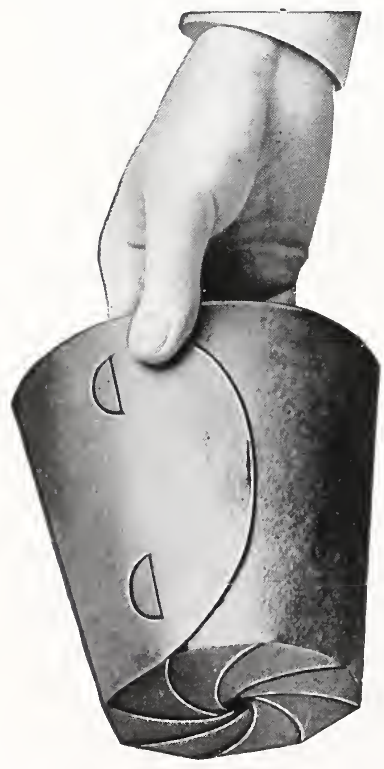

\section{Redwood Urns}

Beautiful, Durable, in a Natural Redwood Color Salmon Pink

For decorative plants or flowers. Free of sapwood. Will outlast metal. Solid one piece bottom, pedestal legs; sides of solid 1-inch clear boards with moulded corners to conceal joints; mitered top moulding to effect massiveness, yet not out of proportion. Nothing like it on the market. Knocked down and packed in carton with instruction and nails for assembly. Shipping weight, 9 lbs. Size $12 \times 12$ inside diameter. $\$ 2.75$ each P. P. or Exp. collect.

\section{Redwood Decorative Flower Boxes}

For the window. P. P. or Exp. Collect.

8 in. by 8 in. by 2 ft. Wt. 8 lbs. Each. $\$ 1.35$

8 in. by 8 in. by $3 \mathrm{ft}$. Wt. $11 \mathrm{lbs}$. Each.......... 1.85

8 in. by 8 in. by 4 ft. Wt. 14 lbs. Each.......... 2.25

\section{Neponset Flower Pots (Paper)}

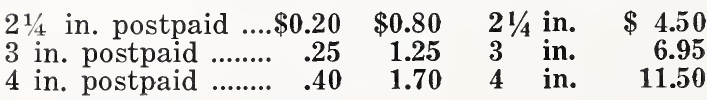




\section{Cactus Gardens in Bowls}

Carefully arranged. Very ornamental. From 65 c to $\$ 5.00$ each, prepaid.

\section{Fancy Flower Vases and Jardinieres}

Prices ranging from $\$ 1.00$ to $\$ 2.50$ each, prepaid.

FLOWER HOLDERS. 21/2 inches, 43c each, postpaid.

\section{Artificial Wreaths}

Natural prepared wreaths, splendid values at a price range of $\$ \mathbf{2 . 3 0}, \mathbf{\$ 3 . 0 0}$, $\$ 4.00, \$ 5.00, \$ 7.50$ and $\$ 10.00$ each, prepaid.

\section{Baskets of Artificial Flowers}

Artistically arranged, made up of all kinds of flowers, fine combinations at $\$ 1.25, \$ 1.50, \$ 1.75, \$ 2.00, \$ 2.50$ and $\$ 3.50$ each prepaid.

\section{Artificial Flowers, Etc. (Prepaid)}

STRAWFLOWERS. Per dozen, 38c.

BABY'S BREATH. Dried per bunch, 29c, white or red.

CAT TAILS. Fancy, two tone color, large, 3 for $45 \mathrm{c}$; 6 for $75 \mathrm{c}$.

Fancy, two tone color, medium, 3 for $28 \mathrm{c} ; 6$ for $45 \mathrm{c}$.

BOUQUET OF ARTIFICIAL FLOWERS. 75c each.

RUSCUS. Dyed red or green, 25c per bunch.

\section{Cutflower and Plant Baskets}

Ranging from 60c to $\$ 5.00$ each, prepaid.

\section{Ferneries}

Ranging from $\$ 4.25$ to $\$ 6.00$ each, shipped express collect.

\section{Gold Fish}

Shipped by Express Only-Minimum Shipping Charges About 40c

Small goldfish

$\$ .15$

Medium size .25

Shubunkins .25

Larger size

$.35 \mathrm{c}$ and .50

Fantails

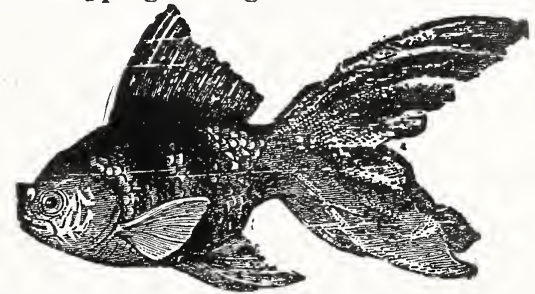

Black Telescopes

Large, bulging eyes.

75c and 1.00

PAILS FOR SHIPPING FISH. At cost, 15c, 25c, 40c and 60c each.

"THE AQUARIA". Paper covered booklet, well illustrated, 28c prepaid.

\section{Turtles and Snails (Postpaid Prices)}

Baby Turtles, fancy, 40c each, 3 for $\$ 1.10$.

Snails, 4 for $25 c$.

\section{Fish Foods (Postpaid)}

Fish food in paper box (for gold fish), 17e per box.

Wafer fish food, full size package, 15c per package.

Japanese Shrimp, finest quality, 22c per package. 

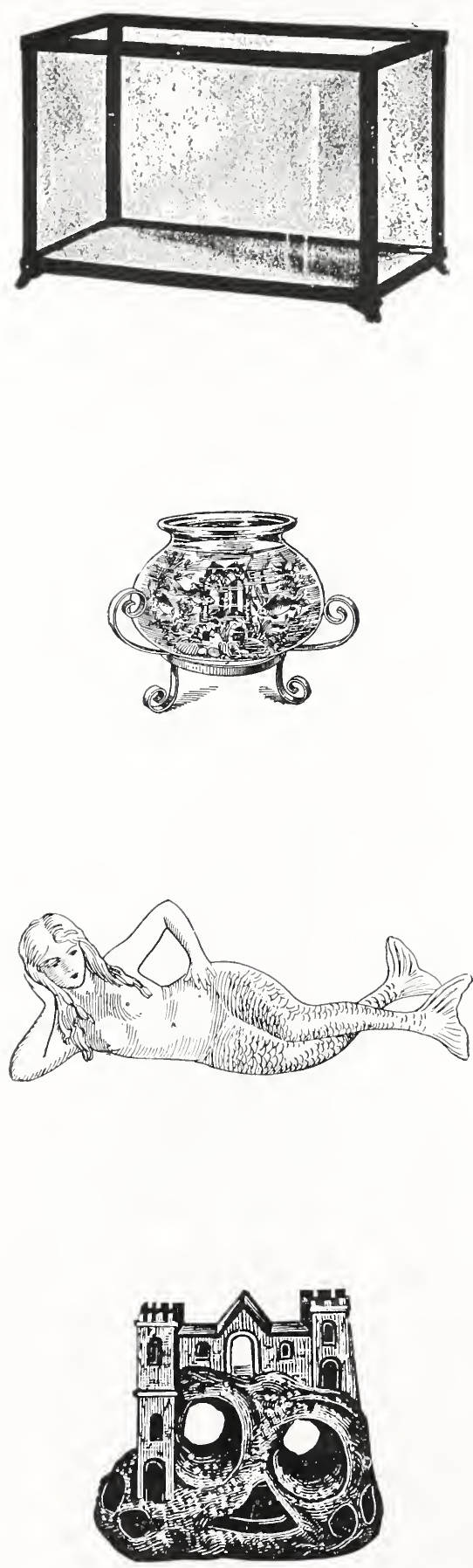

\section{Aquariums}

By Express or Freight Collect

Style 800 B, round, all clear glass, 10 inch diameter. 2 gall. capacity with table stand No. T10. Shpg. Wt. 7 lbs. Price $\$ 3.95$ complete.

Size No. 102, $12 \times 7 \times 7$ inches, 2.3 gal. Shpg. Wt., 8 lbs. Price $\$ 3.95$.

Size No. 103, length 14 in., width 8 in., height, 10 in. Shpg. Wt. 11 lbs. Capacity 4.1 gal. Price $\$ 1.95$.

Size No. 104, length 16 in., width $91 / 2$ in., height 10 in. Shpg. Wt. 14 lbs. Capacity 6 gal. Price $\$ 5.95$.

\section{Fish Globes}

\section{Very Carefully Packed}

Style

Capacity Shpg. Wt. Price

B Squat shaped.... $1 / 2$ gal. 2 lbs. \$0.35 each

B Squat shaped.... 1 gal. 3 lbs. .55 each

F Drum shaped.... 1/2 gal. 2 lbs. .40 each

F Drum shaped.... 1 gal. 3 lbs. .75 each

F Drum shaped.... 2 gal. 5 lbs. 1.10 each

S Green glass........ 3 gal. 7 lbs. 3.75 each

P Clear glass........ 21\% gal. b lbs. 1.35 each

P Blue glass......... 21/2 gal. 6 lbs. 2.10 each Add Postage

\section{Stands for Fish Globes}

No. $S 61 \frac{1}{2}$ for style $F, 1$ gal. bowl, height 32 in., Shpg. Wt. 3 lbs.....................................

No. T61/2 T Table stand for style F, 2 gal. Shpg. Wt. 2 lbs...........................................

No. T1/2 T Table stand for style B, $1 / 2 \mathrm{gal}$. Shpg. Wt. 1 lb. .25

No. T1 T Table stand for style B, 1 gal. Shpg. Wt. 1 lb.

\section{Add Postage}

.35

\section{Fish and Aquarium Supplies}

\section{Prices Postpaid}

AQUATIC PLANTS. Fish moss in bunches, per bunch, 25c.

PEARL CHIPS. For fish bowls, plain or colored. Very attractive. $1 / 2$ lb. $15 c ; 1$ lb. 22c.

HEALTH DIP. For prevention and cure of fungus. 1 oz. $48 c$

FUNGUS REMEDY. 1 oz. $48 \mathrm{c}$.

AQUARIUM CEMENT. To mend breaks in cracked glass. 3 ozs. 30 c.

DIP NETS. 3 inch diameter, gauze, for tropical fish, 12 inch wire handle. 20c each.

DIP NETS. 4 inch diameter round cord nets, 16 inch wood handle, 35c.

Floating celluloid animals, ducks, turtles, swans, frogs, etc., 13c each, $\$ 1.20$ per dozen.

BALANCING ORNAMENTS for fish bowls. (Cat with fish in mouth etc.) Each 40c; 3 for $\$ 1.00$.

MERMAIDS. Imported attractive ornaments. Will not fade. 95c each.

\section{Castles}

Height Price

For fish bowls and aquariums 3 in. $\$ 0.25$ each For fish bowls and aquariums 4 in.

For fish bowls and aquariums 5 in.

For fish bowls and aquariums 6 in.

For fish bowls and aquariums $10 \mathrm{in.}$
0.25 each .50 each .75 each 2.40 each 


\section{BIRDS}

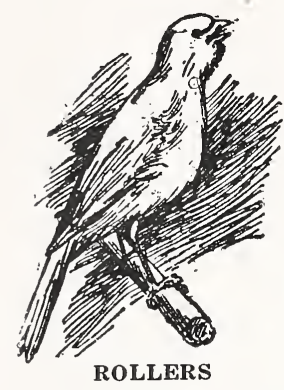

St. Andreasburg and Seifert Rollers, (Males)

Fine grade of German imported birds, price depending on notes and calls. Fine singers at $\$ 11.00$ each. Selected singers at $\$ 12.50$ each.

\section{Female Canaries For Breeding}

Domestic, dark and mixed. $\$ 1.50$ and $\$ 1.75$ each.

Domestic, yellow. $\$ 2.00$ and $\$ 2.50$ each.

Imported, roller stock, Each, $\$ 3.00, \$ 4.00$ and $\$ 5.00$.

\section{White Canaries, (Males)}

Fine imported Rollers, $\$ 15.00$ each.

Selected grade, imported Rollers, $\$ 17.50$ each.

\section{Strawberry Finches}

Very pretty, charming sweet song. $\$ 9.00$ per pair.

\section{Australian Shell Parokeets or Love Birds}

Trifle larger than Canaries. Can be taught amusing tricks. $\$ 10.00$ per pair.

\section{Parrots}

Red Head Mexican Parrots. \$12.00 each.

Double yellowhead Mexican Parrots, $\$ 15.00$ each.

Panama Parrots, \$22.50 each.

Cuban Parrots, July to Sept. only, $\$ 9.00$ each.

Prices on all birds and pets, subject to change without notice.

Shipments travel at customer's risk.

Birds are shipped by express in small shipping cages, charges collect.

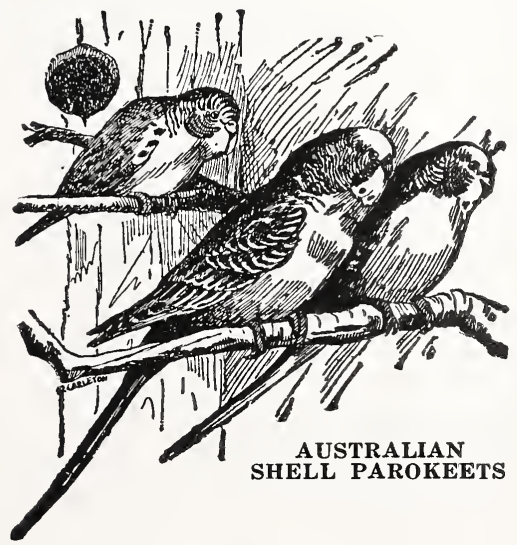

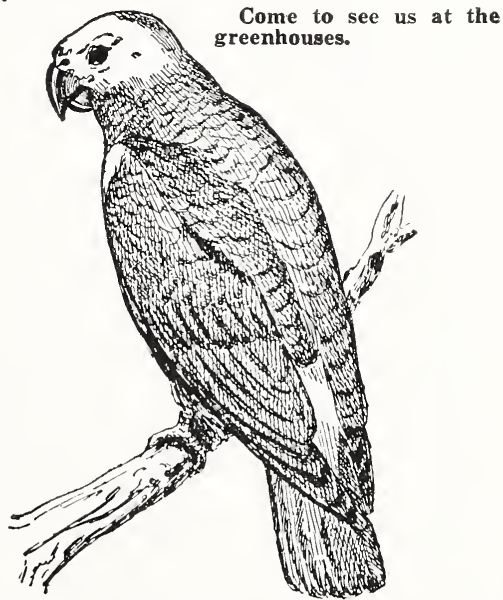

Japanese Robins

Remarkable Songsters

Dark green color, except breast of orange yellow blend, rivaling European Nightingale in song. $\$ 10.50$ each.

\section{MONKEYS}

Different kinds, ranging from $\$ 25.00$ to $\$ 40.00$ each.

PRICES on all kinds of Pets quoted on special request as we cannot list them all due to lack of space. 


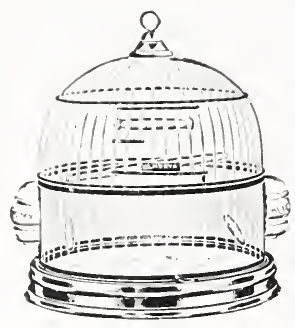

\title{
BIRD GAGES
}

Can be shipped by express or parcel post. Customer pays transportation.

No. 521G Solid brass, round cage, 101/4 in. diameter, satin dip. Shpg. wt. 3 lbs. Each \$3.25.

No. 521G\&S. Brass cage with stand No. 51. Wt. 12 lbs. Black and brass effect, ornamental base and polished loop. \$6.15 complete.

No. 521S. Stand for above, wt. 9 lbs. $\$ 3.10$ each.

No. 521EE. Japanese style, polished brass, 101/4 in. diameter, wt. 5 lbs. $\$ 8.95$ each.

No. 111E. Brass cage stand, fancy, for No. 521EE cage. Wt. 10 lbs. Each $\$ 8.95$.

No. 521EE \& $111 \mathrm{E}$ cage and stand. Wt. 14 lbs. $\$ 16.25$ complete.

The same in gun metal finish. Wt. $14 \mathrm{lbs}$. $\$ 16.75$ complete.

No. 5261. Japanese style cage in red, green or blue colors, with brass hilite and drawer bottom. Wt. $14 \mathrm{lbs}$. \$9.25 each.

No. 1061E. Stand for above, in red, green or blue. Wt. $10 \mathrm{lbs}$. \$5.25 each.

No. 5261EE with $1061 \mathrm{E}$ cage and stand complete. Wt. 14 lbs. \$13.95.

\section{ACCESSORIES (Cage Cups, etc.)}

\section{Prices Postpaid}

BATH DISHES. Large size. 25c each.

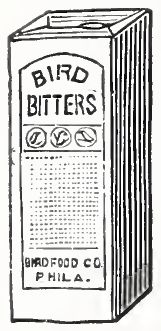

OPAL SEED CUPS. 21c each.

WIRE BREEDING NESTS. With swivel No. 20, 18c each.

Lice proof nesting material. 15c per pkg.

Bird cage springs, single. 16e each.

Bird cage brass brackets. 25c each.

Cretonne cage covers. To protect birds at night. 95c and $\$ 1.15$ each.

Cretonne seed guards, to prevent seeds from being scattered all over the floor. \$1.35 each.

\section{Bird Foods and Preparations \\ Postpaid}

In cartons with directions printed on package. FINEST QUALITY

"EMIL'S" Canary bird seed, our own mixture. 20c per pkg.

“FMIL'S" Love bird seed, our own brand. 25c per pkg.

"EMIL'S" Millet seed for Finches. 25c per pkg.

Sunflower seed, per lb. at 22c.

Color and Pepper food, per pkg. at $28 \mathrm{c}$.

Song restorer and Moulting food, $28 \mathrm{c}$ per pkg.

Cuttlebone, 9c per piece or 3 for $25 \mathrm{c}$.

Bird Tonic Balls, $15 \mathrm{c}$ each or 2 for $27 \mathrm{c}$.

Bird Tonic liquid, per bottle at $28 \mathrm{c}$.

Bird salve for sores, etc. Per pkg. at $27 \mathrm{c}$.

Egg and nesting food, per pkg. at 30c.

Parrot tonic, for colds and asthma. $40 \mathrm{c}$ per bottle.

Lict powder, for lice, mites, etc. 30c per pkg.

Bird delouser, a liquid remedy. Per bottle, 40c.

Bird gravel. 3 lbs. for 48 c.

Bird gravel paper for round cage bottoms. 5c each, 12 for 50 .

\section{Catnip Mice}

\author{
Postpaid
}

Catnip, covered with cloth, shaped like a mouse. 18c each.

\section{Illustrated Books}

\section{Postpaid}

Canary breeding and training. 30c each.

Parrots and other talking birds. 38c each.

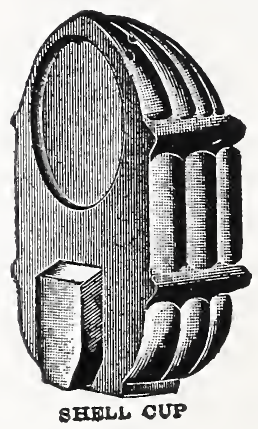

SHELL CUP

Parrots and other talking birds.

Feathered pets. 38c each.
Gold Fish and Aquaria. 30c each. 


\title{
NURSERY DEPARTMENT
}

\author{
It's not a "Home until it's planted"
}

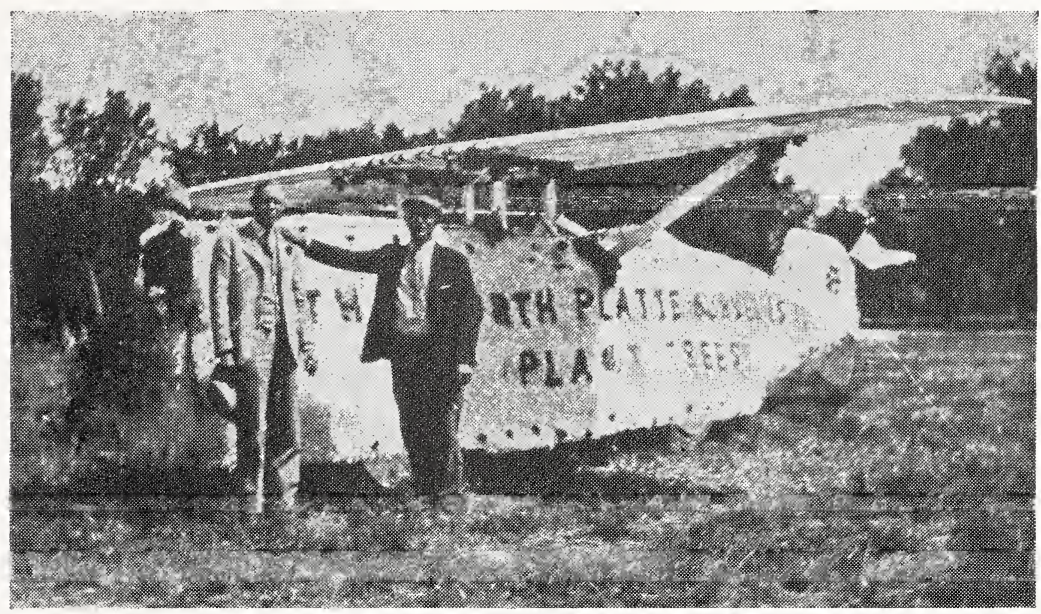

“1928 Nursery Float" Mr. Rathman and Mr. Mersheid in Foreground.

GENERAL INFORMATION. Our Nurseries are inspected annually and certificate of in. spection accompanies each order of stock.

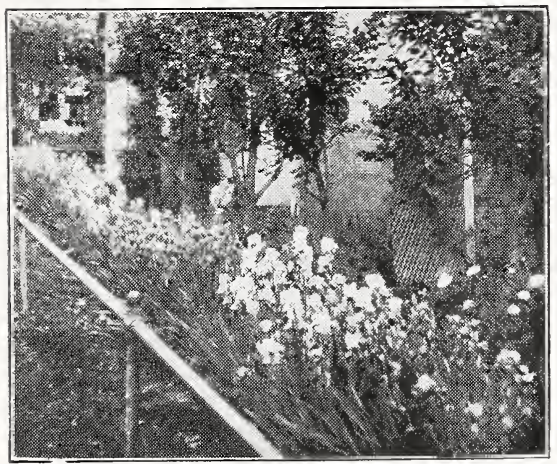

PLANTING instruction booklet furnished free with each order of stock. Look for it in your bundle or bale. Don't fail to ask for special Chinese Elm Folder or "How to Plant the Home Grounds" booklet if interested.

ORDERS for nursery stock will be booked as received and shipment made in proper planting season. Early orders receive particular attention besides the special cash discount of $5 \%$ if received before April 1st. Order yours right now.

ALL STOCK is carefully packed, balled or boxed, F. O. B. North Platte and will be shipped by freight or express collect unless otherwise noted. We will ship any plants or trees by mail if under three feet, cut back

ready for planting, if you wish, paying parcel post charges on receipt of the stock at your door.

EVERGREENS. B. \& B. or balled and burlapped can be sent either by express, or we can box and ship by freight.

SUBSTITUTION. We do not substitute unless requested. We furnish only "true to name" stock or your money back.

TERMS AND CONDITIONS. See pages 2 and 3 .

RATES. Anything in this Department, 5 at the 10 rate, 50 at the 100 rate, 500 at 1000 rate.

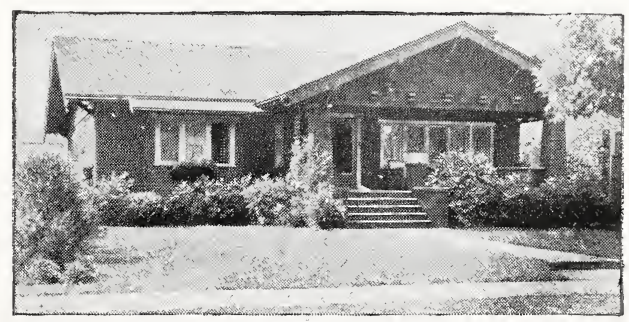




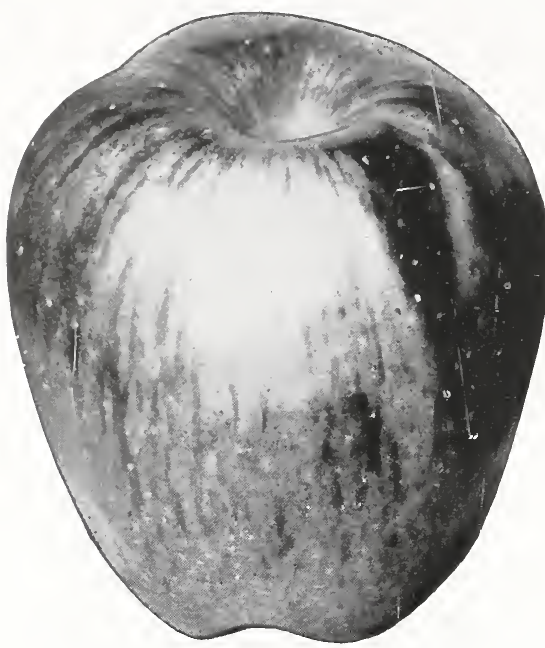

Special parcel post prices: 1 yr. grafts, 11/2$3 \mathrm{ft} ., 25 \mathrm{c}$ each; $\$ 2.00$ per $10 ; \$ 17.50$ per 100 .

\section{Summer and Fall Apples}

WEALTHY. The best all around Fall variety for all purposes. Bears very young and annually. Tree very hardy. Quality the best.

YELLOW TRANSPARENT. Our earliest yellow apple. Tree hardy, upright, requiring very little room; productive, bears extremely early. Fruit medium to large, uniform in shape and size, fine grained, crisp, juicy, sprightly sub-acid. This is a real good cooker as well as the first eating apple of the season. The early money maker. July and August.

DUCHESS OF OLDENBURG. Large striped red variety. Young and prolific bearer. The leading late summer or early fall sort.

\section{Crab Apples}

All the crab apples we offer are large size, as large as a small sized apple.

HYSLOP. Very dark crimson when ripe. Heavy bearer. The leading crab.

TRANSCENDENT. Earlier than the above. Yellow striped with red. Very juicy.

WHITNEY. Large size. Green striped with red. Heavy bearer and especially valuable for cider making.

SPECIAL. Anoka apple, the earliest tree to bear so far known. Medium size but larger than Duchess. Very hardy.

5-6 ft.

Each $\$ 1.00 ; \$ 9.00$ per 10

4-5 ft.

Each $.75 ; 7.00$ per 10

\section{APPLES}

The King of all fruits and one of the most profitable grown, especially the long keeping kinds such as Delicious, Grimes Golden, Haralson and Malinda which have withstood our severe western Nebraska climatic conditions. We recommend only the hardy, tested varieties listed below. "An apple a day keeps the Doctor away." PLANT MORE APPLE TREES.

\begin{tabular}{|c|c|c|c|}
\hline PRICES, & APPLES AND & \multicolumn{2}{|c|}{ CRABS } \\
\hline & Each & 10 & 100 \\
\hline & $\$ 0.75$ & $\$ 6.00$ & $\$ 50.00$ \\
\hline ft. & $\ldots \ldots$ & 5.00 & 40.00 \\
\hline ft & .45 & 3.50 & 25.00 \\
\hline
\end{tabular}

\section{Winter Apples}

DELICIOUS. The Peer of all winter apples; 2nd degree of hardiness. Nuff sed. Not so hardy north of Central Nebraska.

HARALSON. The recognized Leader of all very hardy, fine winter apples. Fruit large, well covered with solid red. Fine grained, tender and juicy. Excellent quality. KEEPS IN STORAGE UNTIL SPRING.

JONATHAN. Bright red, juicy, snappy flavor. Keeps until middle of summer

NORTHWESTERN GREENING. Fruit similar to R. I. Greening but a much longer keeper and tree a far better and stronger grower.

MALINDA. Medium reddish-yellow fruit. Very good in February and March, Very hardy.

GRIMES GOLDEN. Another of the old varieties still classed among the leaders. Golden yellow, exceptionally fine flavor. Claimed to be susceptible to collar rot.

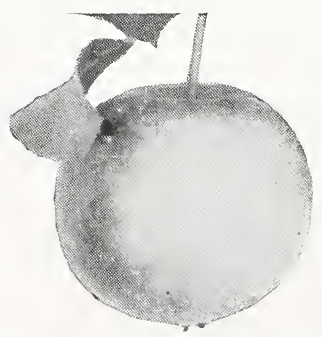

SPECIAL. Dolgo Crab. Oblong shaped with color beautiful solid red. Finest jelly crab known to date.

Prices: Same as for Anoka. 


\section{Plums and Plum-Cherry Hybrids}

We offer herewith, what we believe are the very best varieties of Plums and Hybrids originating from the Minnesota and South Dakota Fruit Breeding Stations, as well as some of the old standby's.

\section{Hansen Hybrids}

Plant Sapa, Opata, Oka and Tom Thumb for early fruit. Will bear first year after planted. Kahinta and Waneta are among the very best of the Hansen introductions and will repay your effort ten-fold in a few years.

\section{PRICES FOR PLUMS}

\section{(Except as Noted)}

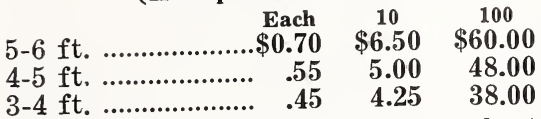

WANETA. Very largest and best for home planting. About two inches in diameter. Good red color. Flavor good.

SAPA. Ripens very early. Flesh red, skin blue or black when ripe. Heavy bearer.

OPATA. Same as Sapa but larger, with green flesh. Both these are excellent for canning.

KAHINTA. Full sister to the Waneta and Tawena plums. About the same as Waneta in size and color but free-stone. Skin thin, no acerbity. Flesh firm, yellow and sweet. Unlike the Waneta, this variety will not overbear but produces a good crop every year. We recommend this variety very highly.

OKA CHERRY. Closest to the real cherry and the best of all the Hansen introductions. Very large, red flesh, small pit. Dries on trees until ready to be picked.

4-5 ft. 85c each $\$ 7.00$ per 10 .

2-3 ft. $50 \mathrm{c}$ each $\$ 4.50$ per 10 .

Tomb Thumb. Similar to Oka but s m aller. Profuse bearer 1 yr. 2-4 ft. 50c. 5 for $\$ 2.00$.

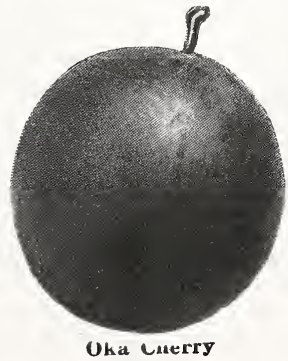

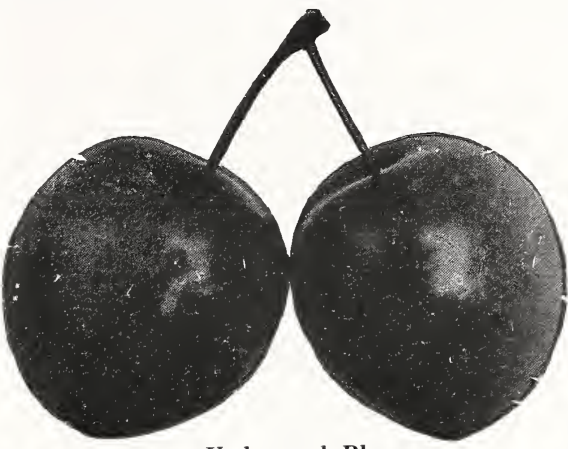

Underwood Plums

\section{German Prune}

\section{(Zwetschgen)}

A large, long, oval variety very good for drying. Color dark purple, very agreeable flavor. Each 4-6 ft. 80c, per $10 \$ 7.50$.

\section{Minnesota Station}

\section{And Other Varieties}

UNDERWOOD. Earliest of the Minnesota plums. Fruit dark red, very small pit. Excellent flavor.

RED WING. Very large, red freestone. Peels like a peach. Very good.

RADISSON. Very large red plum, even surpassing Underwood in flavor.

The above sorts are all hardy and will bear fruit 2nd or 3rd year after being planted. These varieties take the place of our shipped in Califormia plums except that they are so much better in quality that there is no comparison.

COMPASS. Natural Sand Cherry cross origin at ed accidentally at Springfield, Minn., many years ago. Still valuable in Northern regions where less hardy varieties do not thrive. 


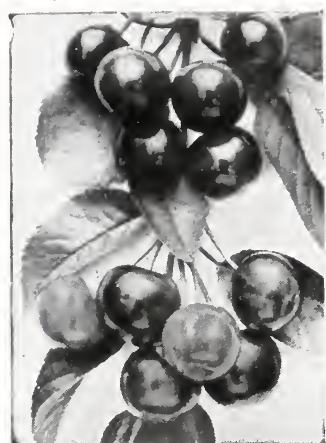

Cherries

\section{Standard Cherries}

\section{(Kirshen)}

EARLY RICHMOND. More extensively planted than all others. Fruit ripens in a shorter period than the other cherries. Earliest of all.

ENGLISH MORELLO. Late, large black. Very hardy in fruit bud. Excellent for canning. Above two varieties not hardy north of Huron, S. D.

MONTMORENCY. Large red, rich, acid, very hardy and productive. Two weeks later than E. Richmond.

\begin{tabular}{rrrr}
\multicolumn{5}{c}{$\begin{array}{c}\text { PRICES } \\
\text { Each }\end{array}$} & \multicolumn{1}{c}{10} & \multicolumn{1}{c}{100} \\
$4-5$ ft. $\ldots \ldots \ldots \ldots \ldots \ldots . \$ 0.75$ & $\$ 6.50$ & $\$ 55.00$ \\
$3-4$ ft. $\ldots \ldots \ldots \ldots \ldots \ldots . .65$ & $\mathbf{5 . 5 0}$ & $\mathbf{5 0 . 0 0}$
\end{tabular}

\section{Currants}

CHERRY CURRANT. Very strong. Large fruit. Red.

WHI'TE GRAPE. White, large, very sweet and productive.

PERFECTION. The very largest and best of all currants and still leading the markets.

\section{PRICES}

Perfection, 2 yr. No. 1, 30c each; $\$ 2.50$ per $10 ; \$ 20.00$ per 100 .

Other varieties, 2 yr. No. 1, 25c each; $\$ 2.00$ per $10 ; \$ 15.00$ per 100 .

\section{Root Crops}

RHUBARB or PIE PLANT.

STRONG 2 yr., 15c each; 10 for $\$ 1.25$. By mail prepaid, 20c each; 10 for $\$ 1.75$.

WASHINGTON RUST PROOF Asparagus, (Spargel). 2 year roots.

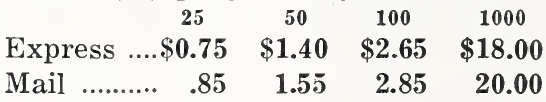

\section{The Mendel Pear}

We feel safe in recommending only one pear for this section, the hardy, blight-proof Mendel originated by the late Wm. Pfaender, Jr., of New Ulm Minn., and introduced several years ago. The original tree has not blighted once in over 25 years and young trees, even though inoculated, resisted the disease. Entirely hardy in the Northwest sections and Canadian points and is being listed and featured by leading nurserymen everywhere. Fruit is larger than the Bartlett and of A No. 1 quality. Very sweet, good flavor and juicy. No grit. Color, golden yellow when fully ripe.

PEAR PRICES

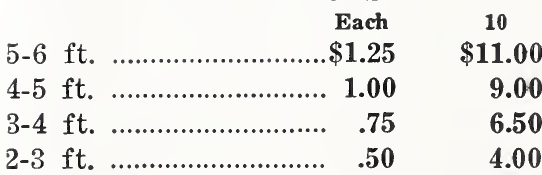

\section{SPECIAL MAIL ORDER PRICES} Each 5

2-3 ft. $\$ 0.60$

$1 \frac{1}{2}-2 \mathrm{ft}$. .45 1.90

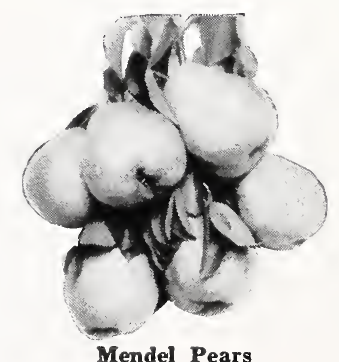




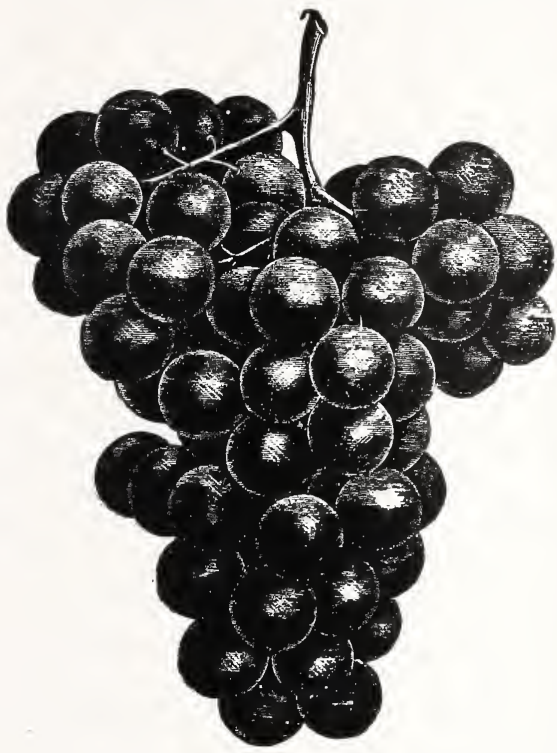

\section{Gooseberries}

CARRIE. Very strong grower and heavy cropper. When fully ripe the berries are of deep purplish red color and delicious flavor. In size, rather small, but large numbers. 25c each; \$2.25 per 10 .

DOWNING. Always dependable. Fruit large, of fine size and appearance. Bush a good grower and heavy cropper. Fine for home use. 25c each; \$2.25 per 10.

HOUGHTON. Next to Downing, this is the most extensively planted. Heavy producer; fruit medium large and of fine quality either green or ripe. Pale red when ripe. 20c each; $\$ 1.65$ per $10 ; \$ 5.50$ per 50 .

\section{Strawberries}

\section{Postpaid}

SPRING BEARING

$25050 \quad 100 \quad 500 \quad 1000$ Senator Dunlap-

$\$ 3.45 \$ \$ 0.80 \quad \$ 1.25 \$ 4.00 \$ 7.50$

Premier-

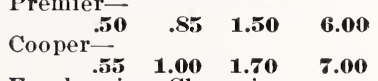

Everbearing Champion-

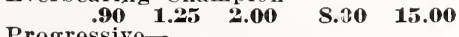

Progressive-

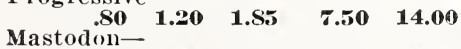

$\begin{array}{lllll}1.00 & 1.85 & \mathbf{3 . 0 0} & 14.00 & \mathbf{2 5 . 0 0}\end{array}$

\section{Raspberries}

CUMBERLAND. Black-cap. Glossy black, sweet. The best of all Black raspberries.

KING. Very hardy and fine for cold climates. Ripens early. Light red, soft.

LATHAM. About a week later than King. The best, finest and largest red raspberry.

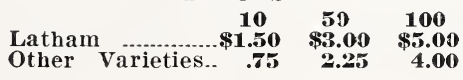

\section{Grapes}

In the long run, bring the biggest returns of all the small fruits, especially the hardy Beta, which does not require winter protection.

BETA. Hardy, very strong grower. Berries blue-black, medium size, pleasant flavor.

CONCORD. The well known, large delicious tasting table grape, black.

LUTIE. One of our best red sorts.

NIAGARA. This is the sweet, large green or white grape. Very good.

\section{PRICES}

Beta, 2 yr. No. 1, 40c each; $\$ 3.50$ per 10 ; \$30.00 per 100 .

Coneord, Niagara, Lutie, 1 yr., each $20 \mathrm{c} ; \$ 1.75$ per $10 ; \$ 15.00$ per 100 .

FREE BOOKLETS We Issue. Ask for them : "Fall Bulb Price List," "Chinese Elm," (Circular), "How to Plant," "How to Use Vigoro," "How to Plant the Home Grounds," "Gator" Hide Mulch Paper."
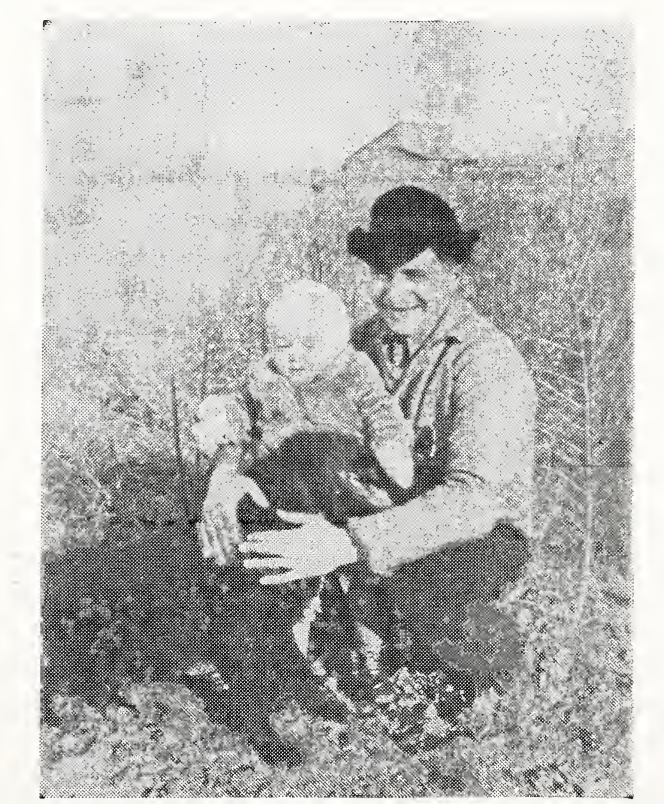

Emil and Eva June Merscheia. Chinese Elm in Back 


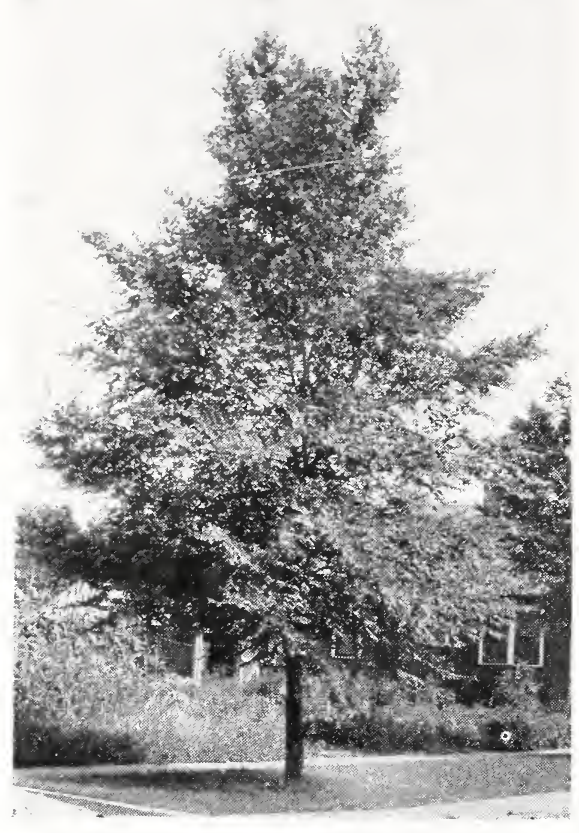

Chinese Elm

\section{Ornamental and Shade Trees}

\section{Chinese Elm}

Ask for Special Circular on This Tree

The most remarkable, talked of tree of the Century. Hardy, very fast growing, disease free, adaptable to all soils and climatic conditions, it is likewise drouth proof and will thrive where other trees fail to live. In China, where it originated, it grows successfully in high altitudes along irrigation ditches and even at 4,500 feet attains a good height. The tree is similar to our American Elm but grows three to four times as fast, is more upright and graceful and makes an equally attractive tree whether planted on the street or boulevard or whether used for grove plantings, windbreaks or hedges. Can be trimmed to any height hedge wanted. We have probably one of the largest blocks of these trees in the Northwest, grown from seed here which was selected and handpicked from specially fine specimens. We offer a complete variety of grades from $1 \mathrm{yr}$. seedlings to two-inch caliber trees, 10 to $14 \mathrm{ft}$. high.

\section{CHINESE ELM}

Prices: Mail or Express Prepaid

1 yr. $2-3$ ft...\$1.35 $\$ 6.00 \$ \$ 10.00$

$\begin{array}{rrrrr}18-24 \text { in... } & \mathbf{. 9 5} & \mathbf{4 . 5 0} & \mathbf{8 . 0 0} & \mathbf{\$ 3 5 . 0 0} \\ 12-18 \text { in... } & \mathbf{. 8 0} & \mathbf{3 . 7 5} & \mathbf{6 . 5 0} & \mathbf{2 5 . 0 0} \\ 6-12 \text { in... } & \mathbf{. 6 0} & \mathbf{2 . 7 5} & \mathbf{5 . 0 0} & \mathbf{1 8 . 0 0}\end{array}$

Tr. trees, frt. or express collect.

\begin{tabular}{|c|c|c|c|}
\hline & Earh & 10 & 100 \\
\hline & & 22 & $\$ 20.00$ \\
\hline & .50 & 4.00 & 35.0 \\
\hline ....................... & .75 & 6.50 & 55.00 \\
\hline ................... & .. 1.50 & 14.00 & \\
\hline & .. 2.00 & 1800 & \\
\hline & 3.00 & .00 & \\
\hline & & & \\
\hline
\end{tabular}

Prices of Following Varieties 5 at 10 Rate Each 10

Norway Poplar...10-14 ft. $\$ 2.00 \$ 18.00$

Norway Poplar 8-10 ft. $1.25 \quad 10.00$

Balm of Gilead... 5- $6 \mathrm{ft} \quad \mathbf{5 0} \quad \mathbf{4 . 5 0}$

Hackberry ........... 5- 5 $6 \mathrm{ft}$. $\mathbf{. 5 0} \mathbf{4 5 0}$

Hackberry .......... 4- 5 ft. $\quad .40 \quad 3.50$

Silver Poplar...... 6- $8 \mathrm{ft} . \quad \mathbf{1 . 5 0}$

Silver Poplar...... 8-10 ft. 200

Lombardy Popl... 8-10 ft. 2.00

Lombardy Popl...10-14 ft. 250

Bolleana Poplar.. 6- $8 \mathrm{ft}$. 1.25

Burr Oak ........... 5- $6 \mathrm{ft} . \quad 1.00$
Prices, Following Kinds Feet Each 10

Russian Olive ....... 5- $5 \quad \$ \quad \$ 1.10 \$ 10.00$

Russian Olive ........ 4- 4 - $\mathbf{8 0} \quad \mathbf{7 . 5 0}$

Russian Olive ........ $3-4 \quad 5000$

Soft Maple ............ 5- 6 (45 $\quad \mathbf{4 . 0 0}$

Mt. Ash ................. 5- $6 \quad .80 \quad 7.50$

Mt. Ash ................. 4- 5 .60 5.00

Am. Elm ............... 4- $5 \quad .35 \quad 3.25$

Am. Elm ............... 3- $3-4 \quad .25 \quad 2.25$

White Birch ......... 5- 6 1.00 900

Honey Locust ........ 6- 6- 8 .70 $\mathbf{6 . 8 0}$

Honey Locust ........ 5- 6 5 $\quad .50 \quad 4.00$

Honey Locust ........ 4- 5 ..35 2.75

Niobe Willow ........ 8-10 8 $1.25 \quad$........

Wis. Wp. Willow... $8-10 \quad \mathbf{1} 20$........

Wis. Wp. Willow....10-12 2.00 .......

Bechtel's Crab ...... 4- $5 \quad 150$........

C. L. Birch Wp....... 8-10 $4.00 \quad$........

C. L. Birch Wp.......10-12 $5.50 \quad$.........

We have many other varieties of trees in small quantities not listed herein which we are glad to quote on request.

11.50 Cottonwood ....................10-14 ft. $\quad \mathbf{1 . 0 0}$

Cottonwood ...................10-14 ft. $\quad \mathbf{f t} .00$ 


\section{Free Trees to Rural Schools}

5 Small Chinese Elm

Free of charge. Send $10 \mathrm{c}$ in stamps to cover mailing charge and we will send 5 Chinese Elm Trees to each Rural School, if you will give us a list of names of the home owners in your district. This includes Minnesota, North and South Dakotas, Nebraska, Wyoming and Colorado. Please apply for free trees not later than April 1st.

SPECIAL: To Rural Schools and Churches only:

6 Chinese Elm, $3 \mathrm{ft}$. transp. for $\$ \mathbf{1 . 5 0}$ 12 Chinese Elm, $3 \mathrm{ft}$. transp. for 2.75

\section{Roses}

Just a few of the very best.

\section{Hardy Roses}

HANSA. Large, double red. One of the best Rugosa type.

SIR THOS. LIPTON. Double white.

BLANC DE COUBERT. Very strong grower. White, semi-double.

PRICES, above kinds, 75c each; 5 for \$3.25. Mail, 85c each.

BUSH ROSES. Hybrid perpetuals.

Ulrich Brumner. Cherry red.

Paul Neyron. Deep pink, fine.

Gen. Jack. Bright crimson.

F. Karl Druschki. Large white.

Gruss an Teplitz. Dark red.

Am. Beauty. Large dk. crimson.

Each, $60 \mathrm{c}$; 5 for $\$ 2.50$. Mail, each $67 \mathrm{c} ; 5$ for $\$ 2.75$.

\section{Climbing Roses}

PAULS SCARLET. Best, brightest, purest red of all climbers.

DR. VAN FLEET. One of the very finest pink climbing roses.

DOROTHY PERKINS. Cherry pink.

EXCELSA. Radiant blood red.

Each 60c; 5 for $\$ 2.50$. Mail, each $67 \mathrm{c} ; 5$ for $\$ 2.75$.

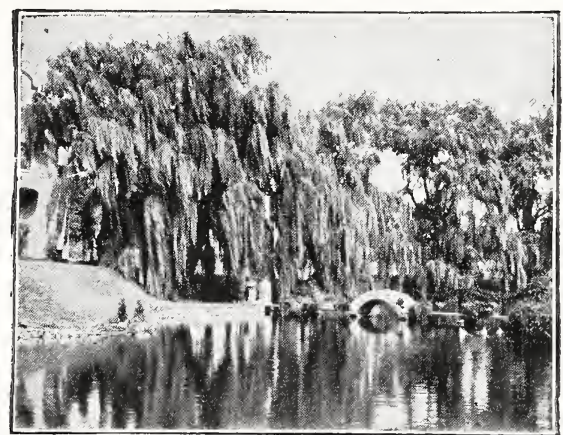

Weeping Willows

Forest Tree Seedlings

Windbreak Stock

American Elm-

$\begin{array}{ccc}50 & 100 & 1000 \\ 12-18 \text { in. ...........\$0.85 } & \$ 1.50 & \$ 13.50\end{array}$

Chinese Elm, see p. 18.

Russian Olive-

$\begin{array}{rrrr}6-12 \text { in. ........... } \mathbf{1 . 5 0} & \mathbf{2 . 5 0} & \mathbf{2 0 . 0 0} \\ 12-18 \text { in. ........... } & \mathbf{2 5 0} & \mathbf{4 . 0 0} & \mathbf{3 5 . 0 0} \\ 18-24 \text { in. .......... } & \mathbf{3 . 5 0} & \mathbf{6 . 0 0} & \ldots \ldots \ldots . \\ \text { aragana, } 6-12 \text { in. } & \mathbf{1 . 2 5} & \mathbf{2 . 0 0} & \mathbf{1 7 . 5 0}\end{array}$

Russian Gold Will.-

$2-3 \mathrm{ft}$. 2.50

4.00

$3-4 \mathrm{ft}$.

3.50

6.00

POSTPAID PRICES

Add 30c per 50 trees, $45 c$ per 100 trees. Golden Willow, add 2c per tree.

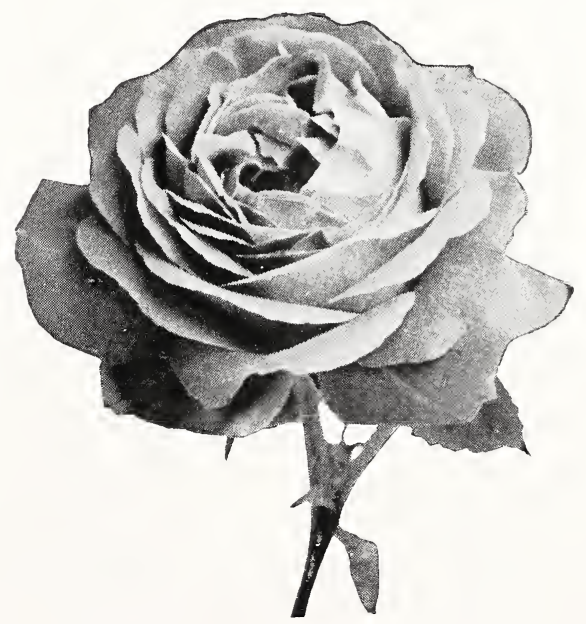




\title{
ORNAMENTAL FLOWERING SHRUBS
}

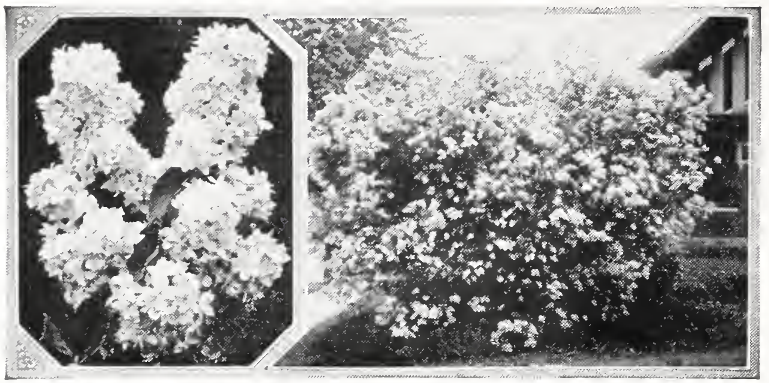

\author{
"It's Not a Home Until \\ It's Planted"
}

Beautify your home surroundings by planting our hardy shrubs extensively, suitable for all purposes. Space does not permit us to describe all varieties, so we will mention just a few of the latest introductions, which we have added to our list.

Persian Lilac

SPIREA VAN IIOUTTE Bridal Wreath Each $\quad 10$

4-5 ft., heavy $\$ 0.75 \quad \$ 700$

3-4 ft., heavy. $.50 \quad 450$

2-3 ft., medium................... . $35 \quad 3.00$

18-24 in., medium............... $\quad .25 \quad 2.00$

GOLDEN SPIREA (Ninebark). 2-3 ft., 40c each; $\$ 3.50$ per 10.

SPIREA BILLIARDI. Red spikes. 2-3 ft., 40c each; $\$ 3.50$ per 10.

SPIREA FROEBELI (Pink), 2-3 ft., 60c each; $\$ 5.00$ per 10.

VIRGINALIS MOCK ORANGE. A vely fine new variety. Double, larger and more fragrant than all the other Nock Orange varieties. 2-3 ft., 75c each, $\$ 3.25$ per 5 .

RED LEAVED BARBERRY. New and wonderfully effective. Blood red leaves from spring to fall. 12-18 in., $60 \mathrm{c}$ each, $\$ 5.00$ per 10 .

PRUNUS CISTENA (Purple leaved sand cherry). Very pretty, hardy shrui with purple foliage used for color contrast and specimens. 2-3 ft., 50c each; $\$ 4.5$ J per 10.

COTONEASTER. Quinceberry. Fine waxy leaves like California privet. Black berries, hardy. 2-3 ft., 75c each; $\$ 7.00$ per 10 .

\section{PRICE LIST FOLLOWING KINDS}

\begin{tabular}{|c|c|c|c|c|}
\hline Spirea A. Waterer- & 10 & Red Honeysuckle.....4-5 ft. & & $\begin{array}{c}10 \\
\$ 8.00\end{array}$ \\
\hline $18-24$ in. ..................... & $\$ 500$ & Morrows H'ysuckle.3-4 ft. & .60 & 5.00 \\
\hline $12-18$ in. .........................50 & 4.00 & Morrows H'ysuckle.2-3 ft. & .40 & 3.50 \\
\hline lthea named kinds $2-3 \mathrm{ft}$. & 600 & Tartarian H'ys'kle..3-4 ft. & .35 & 3.00 \\
\hline nowball ..................2-3 ft. & 5.50 & Com. Mock Orange..3-4 ft. & .50 & 4.00 \\
\hline ydrangea p. g.........2-3 ft. & 6.50 & Com. Mock Orange..2-3 ft. & .40 & 3.00 \\
\hline Hydrangea a. g.........2-3 ft. & 6.50 & Tamarix ...................4-6 ft. & .60 & 5.00 \\
\hline L. Elder................2-3 ft. & 4.50 & Tamarix ...................3-4 ft. & .45 & 4.00 \\
\hline Golden Elder ............2-3 ft. & 4.00 & Coralberry ...........18-24 in. & .25 & 2.00 \\
\hline Syringa Avalanche....18-24 & & Buffalo Berry ........2- $3 \mathrm{ft}$. & .45 & 4.00 \\
\hline nowberry ................ $3-4 \mathrm{ft}$. & 4.00 & Prunus Triloba $\ldots . . . .2-3 \mathrm{ft}$. & .55 & 4.50 \\
\hline Flowering Almond...2-3 ft. & 5.00 & Yellow Dogwood......2-4 ft. & .40 & 3.50 \\
\hline Forsythia G'ld'nbell 2-3 ft. & 3.50 & Red Osier Dogwood.2-4 ft. & .45 & 4.00 \\
\hline Forsythia Weeping..2-3 ft. & 400 & \multirow{4}{*}{\multicolumn{3}{|c|}{$\begin{array}{l}\text { GRAFTED LILACS. Pres. Grevy, } \\
\text { Chas. X, Mme. Abel Chatneay, Belle } \\
\text { de Nancy, } 18-24 \text { in., } \$ 1.00 \text { each; } 2-3 \mathrm{ft} \text {, } \\
\$ 1.25 \text { each. }\end{array}$}} \\
\hline Persian Lilac .............3-4 ft. & 5.00 & & & \\
\hline $\begin{array}{l}\text { Persian Lilac } \ldots \ldots \ldots . . .2-3 \mathrm{ft} . \\
\text { Philadelphus }\end{array}$ & 4.00 & & & \\
\hline Lemoine ................2-3 ft. & 0.00 & & & \\
\hline
\end{tabular}

Sernleaf Sumac ......2-3 ft. $\quad .25 \quad 2.00$

JOSIKAEA LILAC, 2-3 ft., 75c ea. 


\section{Vines and Climbers}

\section{All Strong, Field Grown Plants}

BITTERSWEET. Bright orange colored berries in fall. Strong plants 35c each; $\$ 1.50$ per 5 .

SCARLET T R U M P ET HONEYSUCKLE. B r i g h t scarlet flower and berries. Strong $2 \mathrm{yr}$. , each $40 \mathrm{c} ; \$ 1.75$ per 5 .

HALLS JAPAN HONEYSUCKLE. Nearly evergreen. Pure white flowers changing to yellow. 2 yr. strong, 50c each.

ENGELMANS CREEPER. Very hardy, will cling to stone and stucco. 1 yr., 50c each; \$1.25 per 3 .

VIRGINIA C R E E P E R (Woodbine). Coarser than Engelmans but very fast growing. 25c each: $\$ 1.00$ per 5.

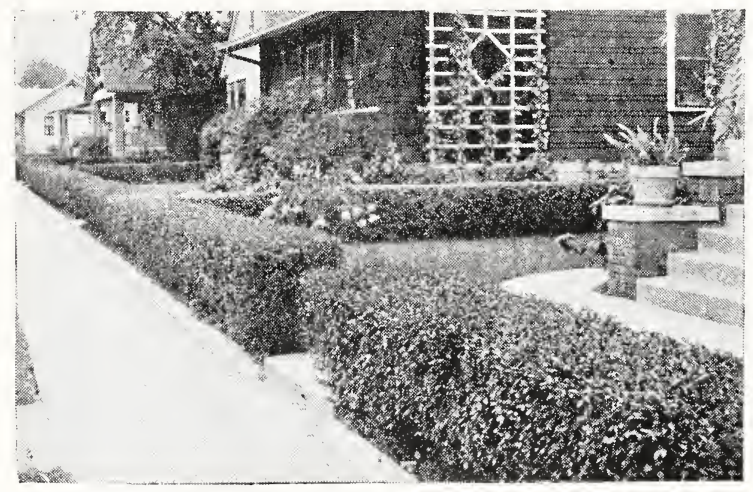

Privet Hedge

CHINESE MATRIMONY VINE. Blue flowers, fast growing. $2-3 \mathrm{ft} ., 35 \mathrm{c}$ each; $\$ 1.50$ per 5 plants.

CLEMATIS JACKMANI. Large purple flowers. Best of all the Clematis. Strong, field grown plants $\$ 1.00$ each.

CHINESE WISTARIA. Bears long clusters of pale blue flowers in May and June. Strong 2 yr., 75c each; 3 for $\$ 2.00$.

Postpaid Prices on any of above plants. Add 10c per plant

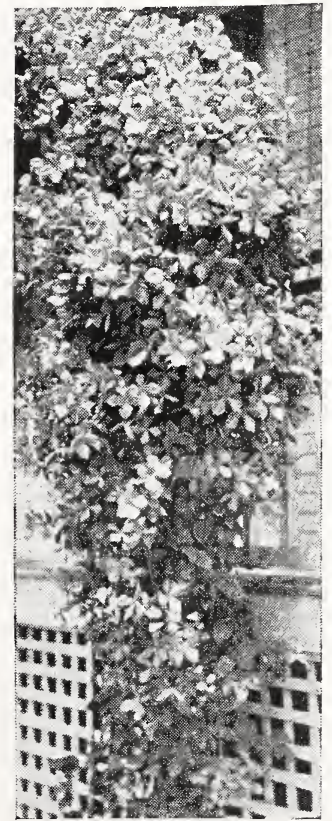

Clematis

\section{Hedge Plants}

To attain a good hedge, plants should be set one foot apart and cut down to within 4 or 6 inches of the ground, after planting. The following hedge plants are all first class transplanted, well branched, bushy stock and should not be confused with $2 \mathrm{yr}$. seedlings grown in the nursery now.

\section{PRICES-ALL TRANSPLANTED STOCK}

\begin{tabular}{|c|c|c|c|c|}
\hline & Each & Per 10 & Per 50 & Per 100 \\
\hline Barberry.........18-24 in. & $\$ 0.35$ & $\$ 3.00$ & $\$ 14.50$ & $\$ 28.00$ \\
\hline Japanese Barberry........12-18 in. & .25 & 2.00 & 9.50 & 18.00 \\
\hline Russian Olive.................... 2- $3 \mathrm{ft}$. & .45 & 4.00 & 18.50 & 35.00 \\
\hline Russian Olive & .55 & 5.00 & 22.50 & 40.00 \\
\hline Caragana ............................18-24 in. & .25 & 2.00 & 8.75 & 15.00 \\
\hline Caragana .......................... 2- $3 \mathrm{ft}$. & .30 & 2.50 & 11.25 & 20.00 \\
\hline Privet A. R.............................. & .20 & 2.50 & 11.25 & 20.00 \\
\hline Privet A. R.... & .30 & 2.75 & 13.50 & 25.00 \\
\hline Privet A. R....................... 2- $3 \mathrm{ft}$. & .40 & 3.50 & 16.00 & 30.00 \\
\hline Russian Mulberry ........ 3- $4 \mathrm{ft}$. & .40 & 3.50 & & 30.00 \\
\hline Russian Mulberry ........ 4- $6 \mathrm{ft}$. & .45 & 4.00 & 18.50 & 35.09 \\
\hline
\end{tabular}

Julesburg, Colorado, February 20.

Sirs: Received the spray this morning and just wanted to write and say-the flowers were beautiful and I was very much pleased. Don't know that I ever saw a prettier spray.

Many thanks for your promptness.

$$
\text { Yours respectfully, }
$$

Mrs. Bruce Campbell.

\section{Potter, Nebraska,} September 27.

Dear Sirs: Please accept my check for $\$ 10$ for one wreath which arrived on time and was very fine.

$$
\text { Yours truly, }
$$

Chas. Gunderson. 


\section{PEONIES}

It is usually best to plant these in September or October, but early spring planting is also very satisfactory. We offer a list of the very finest named varieties, strong 3 to 5 eye roots, priced within the reach of all.

FESTIVA MAXIMA. Still the leading white variety and one of the best ten peonies in existence. 60 c each; 5 for $\$ 2.50$.

EDULIS SUPERBA. Earliest pink. Very large and usually ready for Memorial Day. 45c each; 5 for $\$ 2.00$.

FRANCOIS ORTEGAT. Semi-rose type, midseason. Large, deep, crimson. $75 \mathrm{c}$ each; 3 for $\$ 2.00$.

MONS JULES ELIE. Ideal glossy, lilac pink. King of all peonies. Each at $\$ 1.25$.

MARIE CROUSSE. Soft, salmon pink. Bomb type. Midseason. 75c each; 3 for $\$ 2.00$.

LOUIS VAN HOUTTE. Late midseason, bright red. Medium to large. $65 \mathrm{c}$ each; 5 for $\$ 2.75$.

QUEEN VICTORIA. Guard petals pretty, bluish white, center slightly edged pink. 50c each; 5 for $\$ 2.25$.

COURONNE D' OR. Crown of Gold. Snow white, large, late midseason, semi-rose type. 60c each; 5 for $\$ 2.50$.

KARL ROSENFIELD. Very large, deep crimson and probably the leading commercial variety in use today. Early midseason. $\$ 1.00$ each; 3 for $\$ 2.75$.

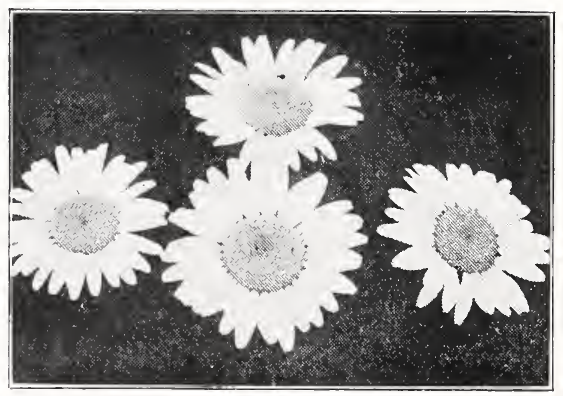

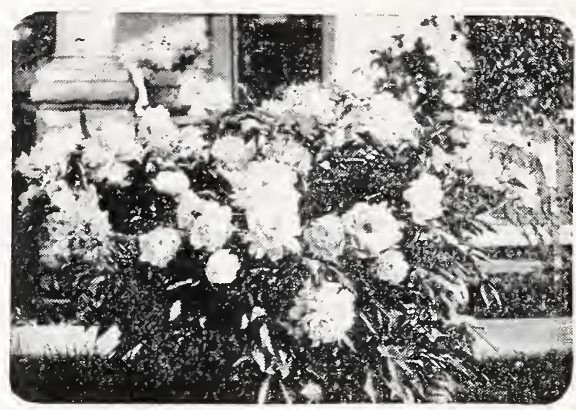

Double mixed peonies. Strong 3-5 eye.

Red, white or pink in separate colors, 35c each, $\$ 3.00$ per 10 .

NIGRICANS. Beautiful dark red, fragrant, very high class. $\$ 1.25$ each; 3 for $\$ 3.15$.

\section{PERENNIALS}

PHLOX. "White, pink or red. 25c each; $\$ 2.50$ per dozen. Named varieties.

ORIENTAI POPPY. Tremendous scarlet, cupshaped blooms. Large blotches, black at base. 30c each; $\$ 2.75$ per dozen.

SHASTA DAISY. 3 inches across, pure white. Each 20c; $\$ 1.50$ per doz.

GAILLARDIA (Blanket Flower). Very showy and effective. 15c each; $\$ 1.00$ per 12 .

LARKSPUR (Delphinium). Blue flowers borne in great profusion on spikes. 25c each; $\$ 2.50$ per dozen.

PENTSTEMON TORREYI. Beards Tongue. Red and the prettiest of all penstemons. 20 each; 6 for $\$ 1.00$.

PLATYCODON. Balloon Flower. Blue, very fine. 20c each; $\$ 2.00$ per dozen.

ACHILlEA. The Pearl. White. 15 c each; $\$ 1.50$ per dozen.

GOLDEN GLOW. 15c each; $\$ 1.50$ per dozen.

MIXED IRIS. All shades. Strong. 15 c each; $\$ 1.50$ per dozen.

BLEEDING HEART. Long racemes of graceful, heart shaped flowers. 65c each; postpaid 75c each. 


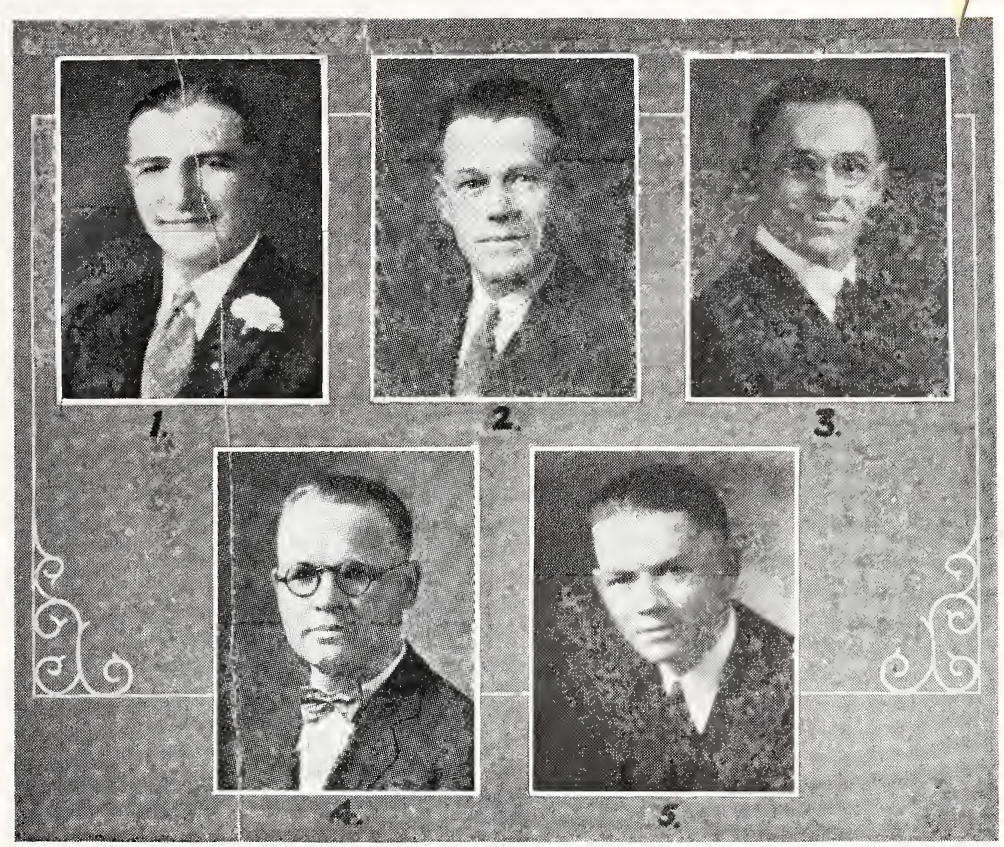

(1)-Emil Merscheid, Proprietor and General Manager, also President North Platte Nurseries, Inc. (2)-Emil Pfaender, Landscilye Architect, (20 years experience) in charge of propagation and sales; former Junior partner Sunshine State Nursery, Yankton, South Dakota; General Nurseryman and Horticulturist at Bismarck, North Dakota. (3)-William Bosch, Credit and Flowershop Manager. (4)-David Rudat, Foreman and Grower. (5)-Leo Anderson, Designing and Shipping Department.

\section{To Our Many, Many Customers and Friends:}

This catalog and price list, combining our Greenhouse, Nursery and Flower Shop products, should give our many out-of-town patrons something we have been asked for many times. This is the first of its type printed, suitable for Western Nebraska, relating to our specife climatic conditions and soils.

THE NORTH PLATTE FLORAL CO. was established in 1917 growing vegetable plants in large quantities, flowers and flowering plants of all kinds, trees, shrubs, strawberry plants, evergreens, etc., and is located on west Twelfth and Curtis streets, with a frontage of three blocks on pavement on highway No. 30. DROP IN. THE FLOWER SHOP is located on Dewey street between Montgomery Ward's and O'Connors Ten Cent Store, where we take care of our many daily customers who want their plants and flowers fresh, canaries and bird cages, gold fish, supplies of all kinds, etc.

THE NURSERIES are located about 6 miles west of North Platte with a display ground, being built up one block east of greenhouses on West 12th Street. The nurseries have grown very rapidly and were incorporated with Mr. E. Merscheid, President; Mr. H. J. Rathman, Vice-President and Treasurer, and Mr. J. C. Holman, Secretary.

\section{Visitors Always Welcome at Greenhouses, Nursery or Flower Shop}

\section{GENERAL INFORMATION}

When Ordering. Cut flowers, potted plants, etc., will be shipped immediately upon request as well as seeds and supplies. Nursery stock, bedding and vegetable plants will be shipped in proper planting season.

Prices are net, F. O. B. North Platte with nursery stock and heavy plants to be shipped by express or freight, collect, UNLESS OTHERWISE NOTED. Seeds, bulbs, cut flowers, supplies etc., will be listed in most cases under postpaid prices.

Terms. Cash with order. On C. O. D. orders of nursery stock, kindly send $25 \%$ of the amount of order.

Special Discount. We offer a special $5 \%$ discount on all nursery stock if orders are received before April $\mathrm{H}, \mathbf{1 9 3 0 .}$

Guarantee. We ship out only first class, clean, healthy stock as described herein. Whenever dissatisfied, write us immediately and adjustment will be made to your complete satisfaction. 


\section{The North Platte Floral Company and Nurseries, Incorporated}

SPRING and FALL 1930 CATALOG

Everything for the Home, Garden and Farm

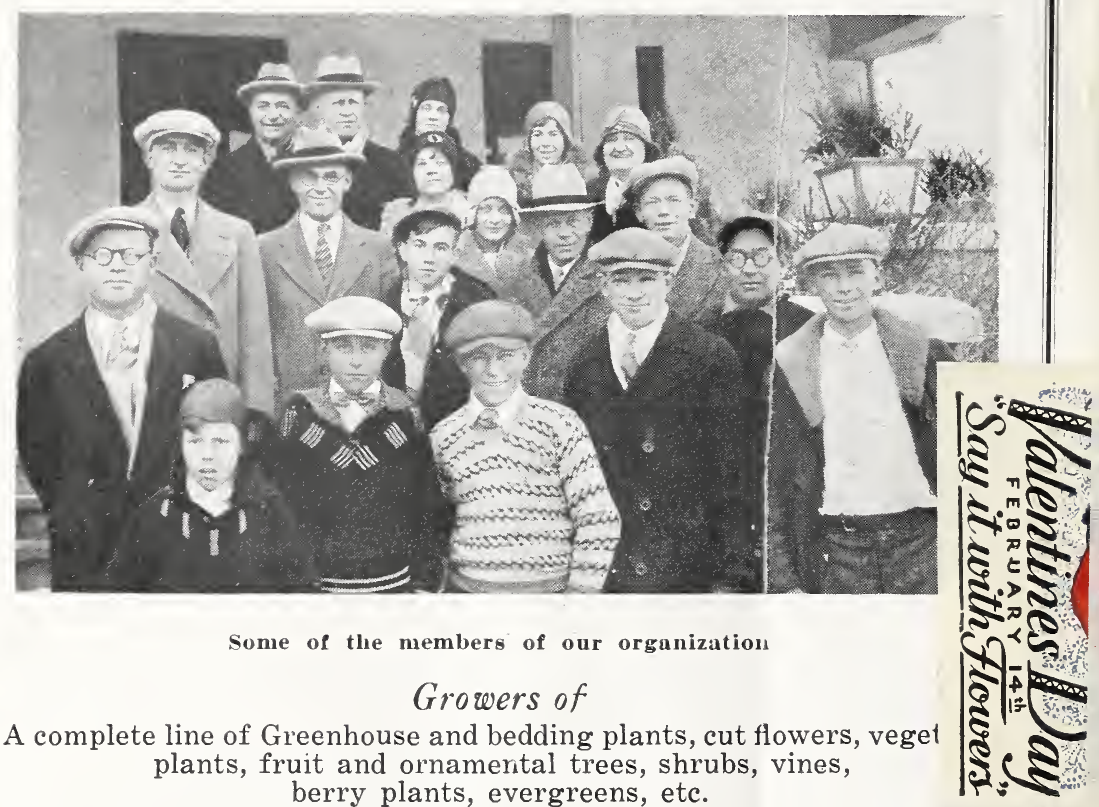

Imported Singers, Goldfish, Bird and Fish Supplies, etc.

Greenhouses-12th and Curtis Streets. Day and Night phone 345 .

Flower Shop-411 Dewey Street. Phone 590.

Open from 8:00 A. M. to 6:00 P. M. Week Days.

Nursery Display Sales Grounds-One block east of Greenhouses. Phones-345 or 590 .

North Platte

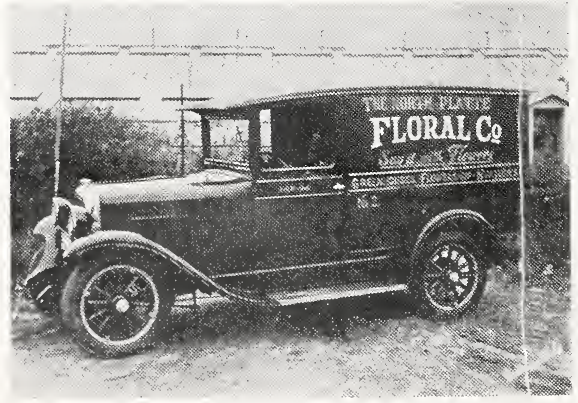

Nebraska 